\title{
Variability and change in the Canadian cryosphere
}

\author{
C. Derksen • S. L. Smith • M. Sharp • L. Brown • \\ S. Howell • L. Copland • D. R. Mueller • Y. Gauthier • \\ C. G. Fletcher • A. Tivy • M. Bernier • J. Bourgeois • \\ R. Brown • C. R. Burn • C. Duguay $\cdot$ P. Kushner • \\ A. Langlois • A. G. Lewkowicz • A. Royer • A. Walker
}

Received: 13 January 2012 / Accepted: 11 April 2012

(C) UKCrown: Environment Canada; (C) Her Majesty the Queen in Right of Canada 2012

\begin{abstract}
During the International Polar Year (IPY), comprehensive observational research programs were undertaken to increase our understanding of the Canadian polar cryosphere response to a changing climate. Cryospheric components considered were snow, permafrost, sea ice, freshwater ice, glaciers and ice shelves. Enhancement of conventional observing
\end{abstract}

Electronic supplementary material The online version of this article (doi:10.1007/s10584-012-0470-0) contains supplementary material, which is available to authorized users.

C. Derksen $(\bowtie) \cdot$ S. Howell $\cdot$ R. Brown $\cdot$ A. Walker

Climate Research Division, Environment Canada, Toronto, Canada

e-mail: Chris.Derksen@ec.gc.ca

S. L. Smith • J. Bourgeois

Geological Survey of Canada, Natural Resources Canada, Ottawa, Canada

M. Sharp

Department of Atmospheric Science, University of Alberta, Edmonton, Canada

L. Brown $\cdot$ C. G. Fletcher $\cdot$ C. Duguay

Department of Geography and Environmental Management, University of Waterloo, Waterloo, Canada

L. Copland · A. G. Lewkowicz

Department of Geography, University of Ottawa, Ottawa, Canada

D. R. Mueller • C. R. Burn

Department of Geography and Environmental Studies, Carleton University, Ottawa, Canada

Y. Gauthier • M. Bernier

Institut National de la Recherche Scientifique, Quebec City, Canada

A. Tivy

Canadian Hydraulics Centre, National Research Council, Ottawa, Canada

P. Kushner

Department of Physics, University of Toronto, Toronto, Canada

A. Langlois $\cdot$ A. Royer

Département de Géographie et Télédétection, Université de Sherbrooke, Sherbrooke, Canada 
systems and retrieval algorithms for satellite measurements facilitated development of a snapshot of current cryospheric conditions, providing a baseline against which future change can be assessed. Key findings include: 1. surface air temperatures across the Canadian Arctic exhibit a warming trend in all seasons over the past 40 years. A consistent pan-cryospheric response to these warming temperatures is evident through the analysis of multi-decadal datasets; 2. in recent years (including the IPY period) a higher rate of change was observed compared to previous decades including warming permafrost, reduction in snow cover extent and duration, reduction in summer sea ice extent, increased mass loss from glaciers, and thinning and break-up of the remaining Canadian ice shelves. These changes illustrate both a reduction in the spatial extent and mass of the cryosphere and an increase in the temporal persistence of melt related parameters. The observed changes in the cryosphere have important implications for human activity including the close ties of northerners to the land, access to northern regions for natural resource development, and the integrity of northern infrastructure.

\section{Introduction}

A frozen white expanse of snow and ice is a popularly evoked image of 'polar' regions. In contemporary scientific terms, we refer to sea ice, freshwater ice, snow cover, glaciers, ice sheets, permafrost and seasonally frozen ground as the cryosphere. This includes the part of the Earth system subject to temperatures below $0^{\circ} \mathrm{C}$ for at least part of the year and contains water in its frozen state (e.g. NRCC 1988). The cryosphere is an integral part of the terrestrial, freshwater, and marine environments of both mid-latitude (seasonal snow and ice; discontinuous permafrost) and Arctic regions (perennial ice; continuous permafrost). In terms of total mass and heat capacity, the cryosphere is the second largest component of the climate system after the ocean (Lemke et al. 2007). Through its influence on the surface energy balance of the Earth and on moisture and gas fluxes within the Earth system, the polar cryosphere plays an important role in Arctic and global climate, ocean circulation, freshwater hydrology, and terrestrial and marine ecosystems (Fig. 1; Walsh et al. 2005; World Meteorological Organization 2007; other papers in this volume). Changes in the cryosphere have direct feedbacks to the climate system: the extent of terrestrial snow and sea ice cover strongly influence surface albedo, while the thawing of permafrost is potentially linked to the release of greenhouse gases to the atmosphere (Prestrud 2007). Melting of glaciers and ice sheets is a major contributor to increases in global mean sea level (Rahmstorf 2010).

There are also important linkages between Arctic ecosystems and the cryosphere because many organisms have adapted to living in, under, or on snow and ice (e.g. Federal, Provincial and Territorial Governments of Canada 2010; Prestrud 2007; other papers in this volume). For example, several species including seals and polar bears rely on sea ice for breeding or feeding habitat as well as for transportation. In the tundra, many species are dependent on an environment of snow and permafrost and the interrelationship between these cryospheric components, and associated land surface characteristics such as vegetation and drainage. Freshwater ice is an important component of aquatic habitat and influences the growing season for algae, water temperature, and oxygen levels, as well as access of wildlife to shorelines and transport across water bodies (Federal, Provincial and Territorial Governments of Canada 2010). Melting of terrestrial snow cover provides a significant seasonal pulse of freshwater runoff, and dominates the water supply for Northern Hemisphere land areas above $45^{\circ} \mathrm{N}$ (Barnett et al. 2005). Changes in glacier volume contribute to changes in 


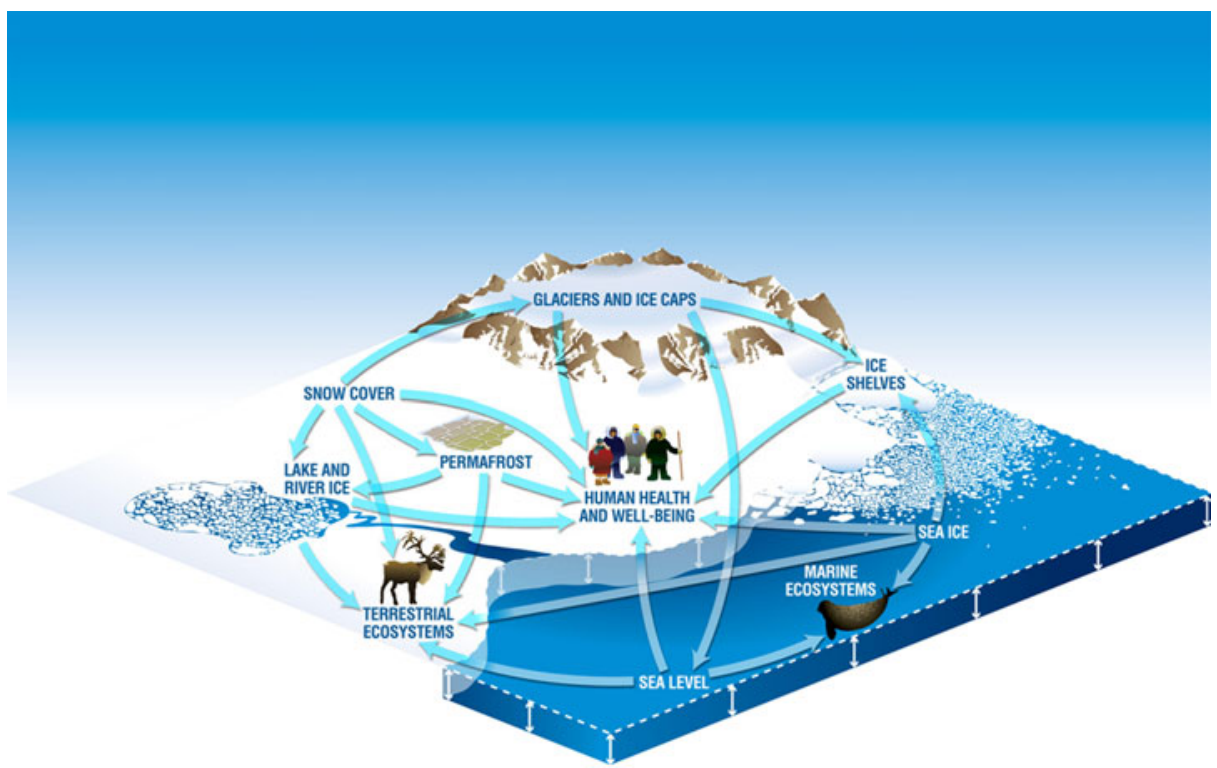

Fig. 1 Conceptual overview of the cryosphere. Arrows indicate process linkages between components of the cryosphere, and connections with ecosystems

sea level which could affect coastal ecosystems, while the freshwater influx related to glacial meltwater can influence marine ecosystems (Walsh et al. 2005). Glaciers also play an important role in regulating river flow and aquatic life through their influence on water availability, temperature and aquatic chemistry. Distinctive microbial ecosystems have been found in snow, sea ice, and permafrost (Vincent et al. 2009; Wilhelm et al. 2011), as well as on and beneath glaciers and ice shelves (Mueller and Pollard 2004; Mueller et al. 2006).

The cryosphere is also an important factor in the traditional ways of life of many northern residents. As well as influencing the abundance and location of terrestrial, freshwater and marine resources on which northerners depend, snow, ice and permafrost also affect human decision-making and accessibility to these resources (Furgal and Prowse 2008). Infrastructure and transportation systems have been designed around or with consideration of the cryosphere. Economic activities, including natural resource development, must consider the challenges presented by the cryosphere for the design, construction, and operation of infrastructure, and cryospheric change must be factored into the assessment of the potential environmental impacts of development and economic activity (Prowse et al. 2009; Furgal and Prowse 2008).

Recent assessments have indicated that dramatic changes are occurring in the cryosphere (e.g. Callaghan et al. 2011; Francis et al. 2009; Furgal and Prowse 2008; Lemke et al. 2007; Rawlins et al. 2010; Walsh et al. 2005). These include declines in Arctic sea ice extent (Tivy et al. 2011a; Stroeve et al. 2011), mass loss from glaciers and ice caps (Gardner et al. 2011; Rignot et al. 2008), decreases in spring snow cover extent and duration (Brown et al. 2010), later freeze-up and earlier break-up of rivers and lakes (Duguay et al. 2006; Brown and Duguay 2011), and warming of permafrost (Romanovsky et al. 2010).

Rising surface air temperatures are a driving force behind these changes. Since 1995, there has been an almost total absence of negative (colder than normal) temperature anomalies (relative to a 1968-1996 reference period) in the seasonal temperature record 
for high latitudes in Canada, as derived from the NCEP/NCAR R1 atmospheric reanalysis (Kalnay et al. 1996; Fig. 2a). Spatial patterns of air temperature anomalies for the primary International Polar Year (IPY) field seasons (2007 and 2008) are shown in Fig. 2b. The trend towards warmer temperatures is especially pronounced in the summer and fall periods because of the transfer of oceanic heat to the atmosphere due to reduced sea ice extent (Stroeve et al. 2011). This process contributes to the 'Arctic Amplification' (Serreze et al. 2009) of global air temperature anomalies, which are further exacerbated by positive feedbacks associated with spring albedo changes over the high latitude land surface (Dery and Brown 2007).

While observed temperature trends are most pronounced during the summer and fall, warming affects the cryosphere across all seasons. For example, warmer spring temperatures induce earlier snow melt, which in turn influences the timing of seasonal peak runoff, the start of the growing season, and geochemical exchange between the land surface and atmosphere. Warm temperature anomalies in the summer produce a longer melt season, which tends to lead to more negative mass balance over glaciers and ice caps, and contributes to decreases in the area and thickness of sea ice. Over the oceans, longer melt seasons allow greater absorption of solar radiation leading to warmer near surface water temperatures that favour later sea ice freeze-up in fall. While high latitude temperatures remain well below freezing during the winter (even when temperatures are above average), a lack of extreme cold temperatures reduces the rate of ice growth (for both lake and sea ice) and the rate and timing of surface temperature rise in the following melt season. Collectively, these temperature-induced impacts on the cryosphere have implications for northern ecosystems, residents, and economic activities, as well as for climate and hydrological systems.

IPY provided a unique opportunity for Canadian cryospheric scientists to conduct comprehensive observational research programs aimed at characterizing the current state of the cryosphere, and understanding how this compares to past norms and variability. The main objectives of cryosphere-related projects were to (1) develop enhanced cryospheric datasets in order to describe current conditions and to place these in a historical context; (2) provide an integrated perspective on the cryosphere and identify both common and divergent patterns of variability and change; and (3) utilize process studies, climate modelling and other analytical approaches to further diagnose and explain the observed variability and change in the cryosphere.

The goal of this paper is to present the key findings from these projects (see Table S1), and synthesize these results to produce an integrated assessment of the state of the Canadian cryosphere during IPY relative to previous decades. Because the majority of projects utilized data from spaceborne sensors, the focus is on the satellite era (1960's to present).

\section{Approach}

Canadian IPY projects employed a range of approaches to document variability and change in the cryosphere. To address gaps in conventional observations, surface measurement networks were improved and augmented. For example, Canada's network for monitoring permafrost thermal state now consists of 170 instrumented boreholes, about half of which were established during the IPY (Smith et al. 2010c). Some of these sites have been in operation for up to three decades with measurements prior to the 1990's made manually at frequencies ranging from monthly to annually. Measurements at all sites are now recorded continuously with data loggers. New methods were developed to produce a standardized record of mean annual ground temperature to allow identification of trends and facilitate comparison with climate data (Throop 2010; Throop et al. 2010). 


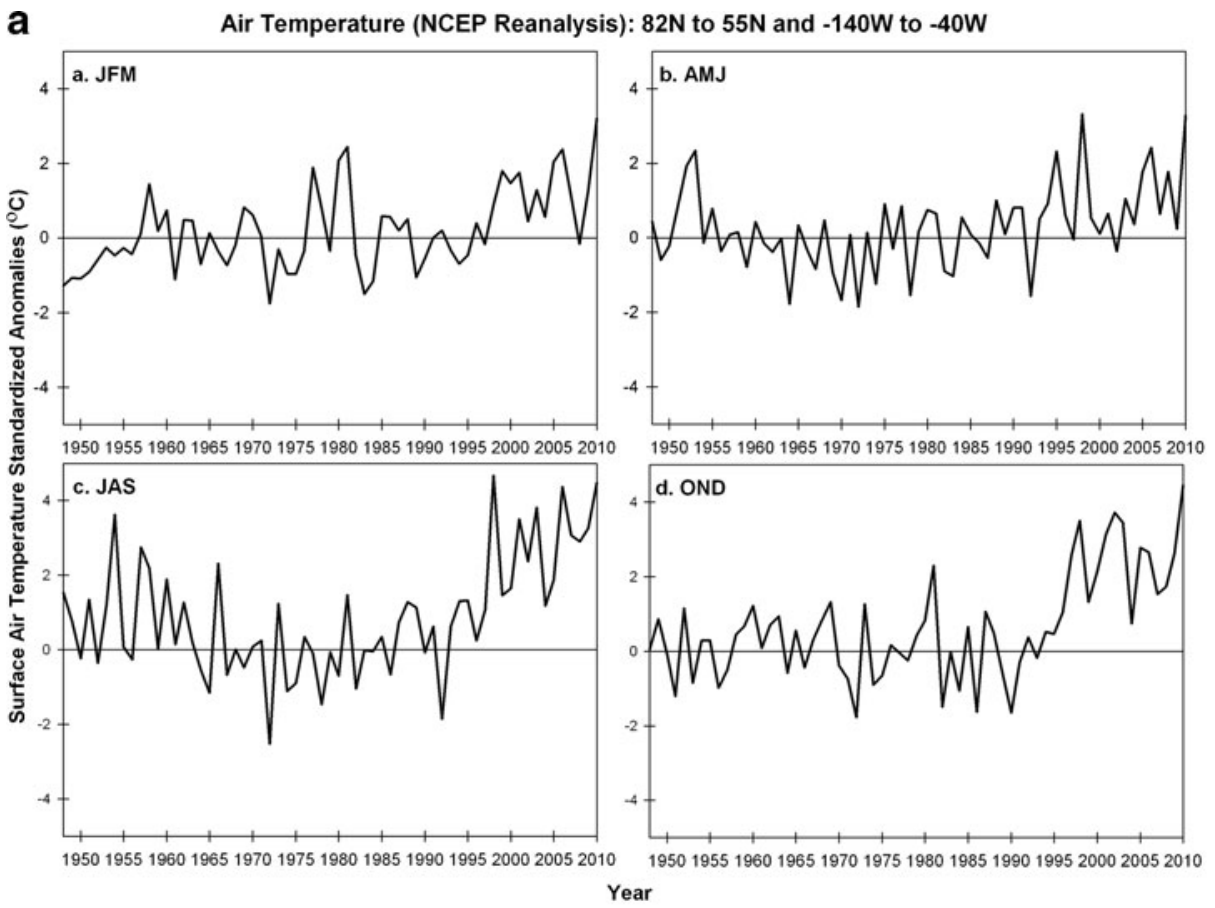

b

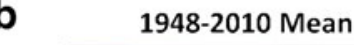

JFM

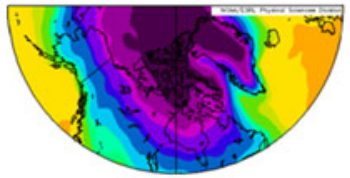

AMJ

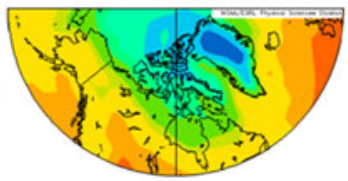

JAS
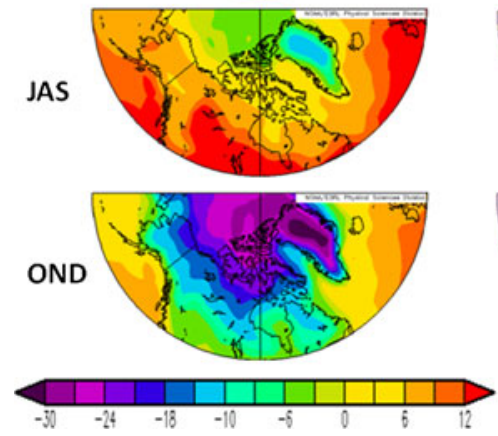

2007 Anomaly
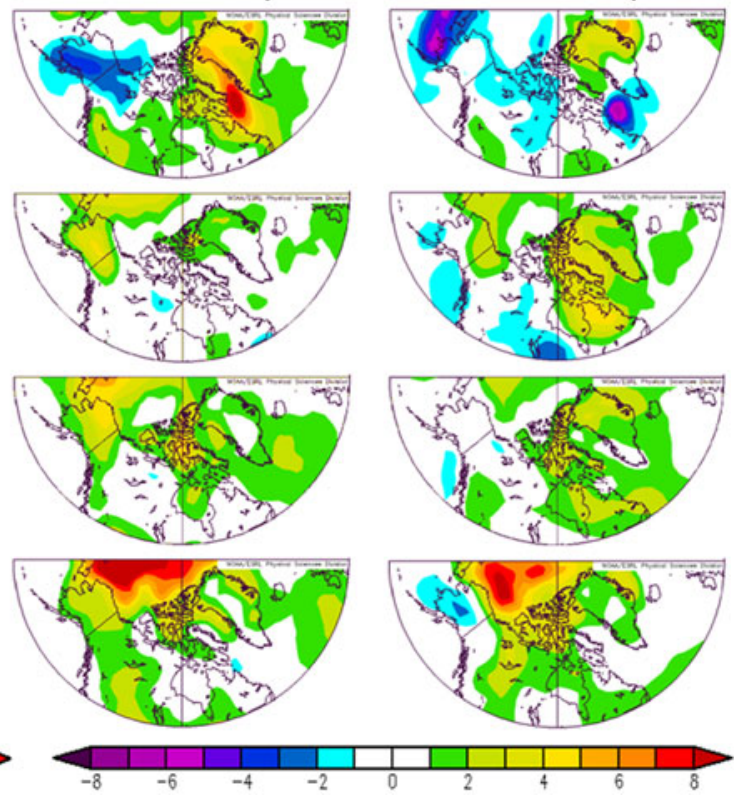

Fig. 2 a Time series of surface air temperature anomalies for the Canadian Arctic, 1948-2010, from NCEP/NCAR reanalysis (Kalnay et al. 1996). b Seasonal mean temperature patterns, 1948-2010, with anomalies for 2007 and 2008 
The vast area of the Canadian cryosphere, and the relative inaccessibility of a large fraction of it, means that most cryospheric parameters (i.e. snow cover, lake ice, sea ice, land ice) are not well suited to conventional surface-based monitoring. Considerable effort was placed, therefore, on the development, enhancement, and/or extension of cryospheric time series using remotely sensed data. This involved developing new algorithms to apply to existing satellite passive microwave, scatterometer, and synthetic aperture radar (SAR) measurements (i.e. Wang et al. 2011; Clausi et al. 2010). Many studies from Canada's IPY activities combined satellite observations with field measurements and model simulations (i.e. Derksen et al. 2010; Langlois et al. 2010, 2011) to produce time series that, when combined with existing datasets from other sources, could be used to more clearly identify and explain trends in cryospheric components.

Another priority was the utilization of underexploited historical datasets. For example, trends in sea ice area and type over the Canadian Arctic were documented using the Canadian Ice Service Digital Archive (CISDA; Tivy et al. 2011a), a compilation of weekly operational ice charts covering Canadian waters from the early 1960s to present that required validation and quality control before use in climate studies. Recent glacier changes in the Torngat Mountains of Labrador were documented using aerial photographs that were well suited to studying these small glaciers $\left(64 \%\right.$ are smaller than $0.25 \mathrm{~km}^{2}$; only 2 are larger than $1 \mathrm{~km}^{2}$; M. Sharp, personal communication).

Canada's IPY activities also spurred unique observational campaigns conducted across the Canadian Arctic. During April 2007, a coordinated series of snow measurements was made across the Northwest Territories and Nunavut, during a $4200 \mathrm{~km}$ snowmobile traverse from Fairbanks, Alaska, to Baker Lake, Nunavut (Derksen et al. 2009). In another unique campaign, Canadian IPY scientists partnered with the Canadian Rangers, a group of highlyskilled reservists from Nunavut, Yukon and the Northwest Territories who train and patrol with the Canadian Forces. To support Canada's IPY science efforts, the Rangers reprioritized their April 2008 patrol to help conduct a traverse of the northern coast of Ellesmere Island, home to Canada's only ice shelves.

Canadian IPY research involved the governments, community organizations, and residents of Canada's north in many aspects of project design and data collection. Several project activities were initiated to meet specific information needs identified by northerners (e.g. Gauthier et al. 2010). Efforts were also made to ensure that data and information generated from projects were publicly available not only for scientific use, but also as a transfer of information to northerners for their use. For example, information collected from community permafrost monitoring sites has been used by the Nunavut Government and community groups in developing climate change adaptation plans and to support infrastructure design (e.g. Ednie and Smith 2010, 2011). Through collaboration between the Canadian Ice Service and Noetix, Inc., weekly maps of the sea ice floe edge produced from SAR imagery were provided to northern coastal communities to assist safe on-ice travel.

\section{Results}

This section provides an overview of the current state of the Canadian cryosphere based on research activities carried out during IPY. Results are presented separately for each component of the cryosphere, with a synthesis provided in section 4. 


\subsection{Permafrost}

Permafrost conditions are intimately linked to hydrological and land surface processes. Change and variability in the ground thermal regime can therefore have significant ecological consequences, while the thawing of ice-rich permafrost can have significant implications for human built infrastructure due to ground settlement if not adequately considered in the design. An important achievement from the Canadian IPY effort was the development of a snapshot (a map and accompanying database) of permafrost temperatures from data collected between 2007 and 2009 at over 100 monitoring sites (Fig. 3a) across the Canadian North (Smith et al. 2010c), a significant update of an earlier map based on temperatures measured in the 1970s and 1980s (Smith and Burgess 2000). Although the spatial distribution of the measurements is uneven, there is adequate coverage from latitudinal transects in western, central and eastern Canada and an altitudinal transect in the Yukon. The measurements are

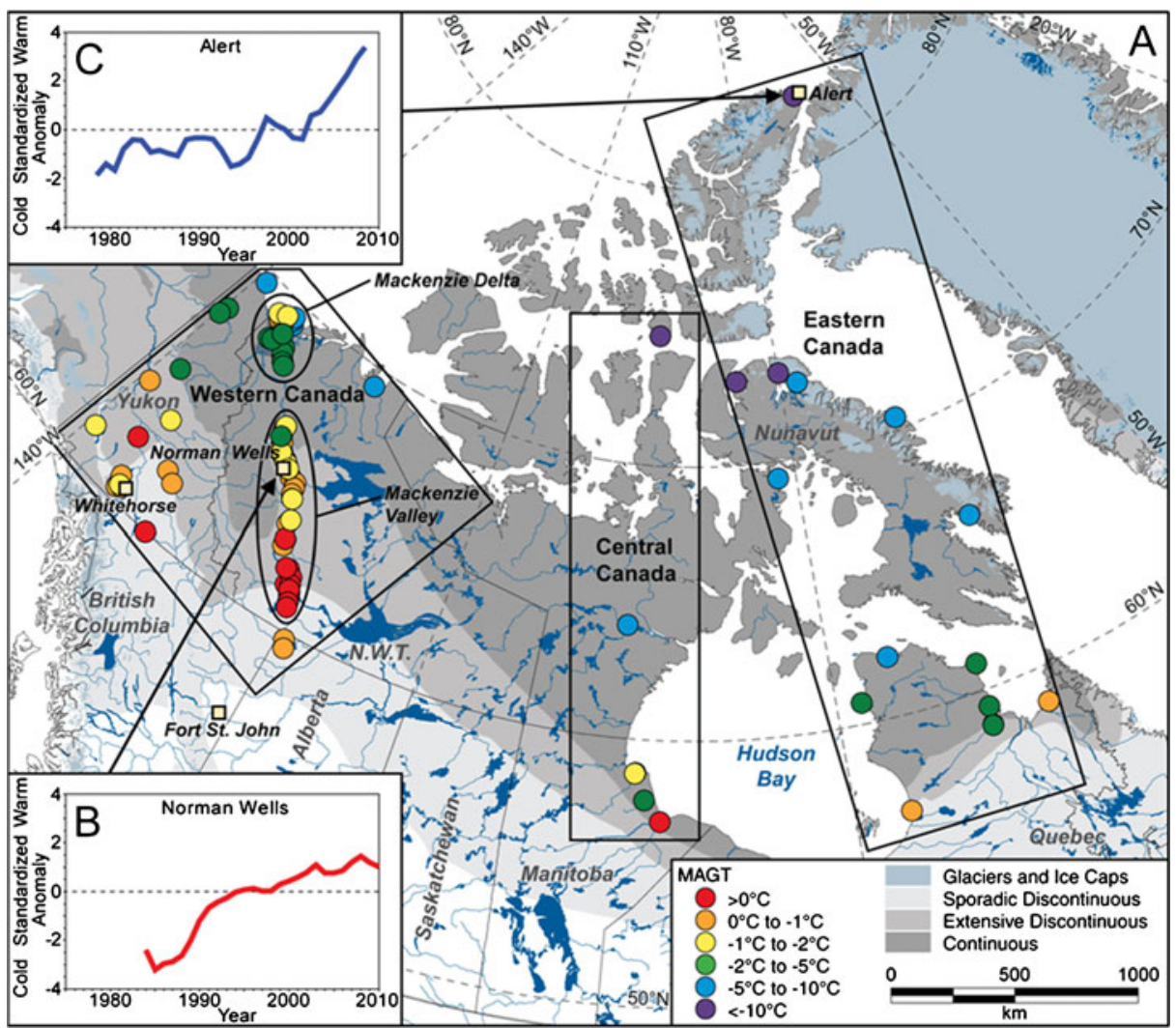

Fig. 3 a Mean annual ground temperature (MAGT) recorded during the IPY (2007-09) from Smith et al. (2010b). MAGT is determined at the depth of zero annual amplitude (depth to which seasonal variation penetrates) or the nearest measurement depth to it. Permafrost zones are from Heginbottom et al. (1995). Location of regions and towns mentioned in the text are also shown. b and c Permafrost temperature standardized anomaly time series relative to 1988-2007 for a site near Norman Wells (depth $12 \mathrm{~m}$ ) in the central Mackenzie Valley and CFS Alert Nunavut (depth $15 \mathrm{~m}$ ) in the Canadian high Arctic 
representative of the wide range of eco-climate and geological conditions that occur across the Canadian North.

The measurements enabled characterization of the range of ground temperatures in the discontinuous and continuous permafrost zones along each transect (see Table S2). The mean annual ground temperature at the depth of zero annual amplitude (or the measurement depth closest to it) in the discontinuous permafrost zone is generally warmer than $-2.5^{\circ} \mathrm{C}$. Permafrost temperatures in the continuous permafrost zone have a much larger range with mean annual ground temperature as low as $-15^{\circ} \mathrm{C}$. There can be considerable local variability within the continuous permafrost zone, especially in areas such as the Mackenzie Delta due to the abundance of water bodies, seasonal flooding, and variable snow conditions associated with differing vegetation cover (e.g. Burn and Kokelj 2009; Smith et al. 2010b). Although terrestrial permafrost was the main focus of the IPY project, recent investigations also provided new information on the thermal state of subsea permafrost in the Mackenzie Delta region (e.g. Solomon et al. 2008; Stevens et al. 2010).

Another significant Canadian IPY research achievement was the establishment of monitoring sites at various elevations in the mountainous terrain of the central and southern Yukon. Prior to the IPY, the thermal characteristics of permafrost in the Yukon mountains were virtually unknown except for the main valley floors. Analysis of a network of 100 air temperature monitoring sites throughout the southern Yukon is providing insights into the role that atmospheric temperature inversions may play in determining the distribution of mountain permafrost (Lewkowicz and Bonnaventure 2011), and indicates that permafrost extent may be much less than predictions made based on air temperature measured at standard weather stations located in the main valley floors (Smith et al. 2010b).

Research during the IPY provided further insights into permafrost-climate relationships, in particular the influence of the characteristics of subsurface sediments and snow cover. The link between the permafrost thermal regime and climate is more direct for sites in cold tundra environments or in low-ice content materials compared to sites under warmer conditions or in ice-rich soils where latent heat effects are significant (Throop 2010; Romanovsky et al. 2010; Throop et al. 2012). The sensitivity of winter ground temperature to snow cover increases as mean annual air temperature increases, but the influence of snow cover also varies with the thermal properties and moisture content of the underlying sediments (Throop 2010; Throop et al. 2012).

Data collected during IPY also allowed the extension of time-series up to three decades for long-term ground temperature monitoring sites. These records show that ground warming is occurring throughout the Canadian permafrost region (Fig. 3b,c), but the magnitude of the warming varies (Smith et al. 2010b, c). In the warm discontinuous permafrost of the central and southern Mackenzie Valley, mean annual ground temperature anomalies show only modest warming (increases up to $0.2^{\circ} \mathrm{C}$ per decade) since the mid $1980 \mathrm{~s}$ (Fig. 3b). Greater changes in permafrost temperature are observed in the colder tundra environments of the western Arctic, with increases of up to $0.8^{\circ} \mathrm{C}$ per decade since the early 1970 s (Burn and Kokelj 2009; Burn and Zhang 2009). In the eastern Canadian Arctic and in northern Quebec warming has been more recent, beginning in the mid 1990s, and varies from no change in the discontinuous permafrost zone to up to $+1.2^{\circ} \mathrm{C}$ per decade in colder permafrost or at bedrock sites. In the Canadian high Arctic, warming has been occurring since the $1980 \mathrm{~s}$, but the rate of warming has increased since the 1990 s (Fig. 3c) to almost $1{ }^{\circ} \mathrm{C}$ per decade.

A comparison of trends from Canadian sites with those from monitoring sites throughout the Polar regions indicates that temperature increases are generally smaller in warmer icerich permafrost (Romanovsky et al. 2010). Regional similarities also exist between Canadian sites and those elsewhere in the Polar regions. For example, patterns in permafrost 
temperature change in western Canada are similar to those in Alaska, while those in the eastern and high Canadian Arctic are similar to those in Nordic regions (particularly Svalbard) which show a more recent ground temperature increase (Romanovsky et al. 2010). Analysis of climate data in combination with ground temperature records from northern Canada indicates that increases in winter air temperatures are largely responsible for the observed increases in ground temperatures (Throop et al. 2010). The increasing winter air temperatures have a greater effect on ground temperatures where snow cover is minimal than at sites with significant snow cover.

Evidence of changing permafrost conditions also comes from field investigations along the Alaska Highway Corridor between Whitehorse YT and Fort St. John BC (Fig. 3a). A comparison of observations of permafrost occurrence made during the IPY with those made at the same sites in 1964 shows that permafrost is degrading at more than half the sites revisited (James 2010; James et al. 2010). Where permafrost still exists, it is thin (e.g. Lewkowicz et al. 2011) and largely restricted to organic soils, similar to the discontinuous permafrost in southern NWT and northern Alberta (Smith et al. 2008). Warm ice-rich permafrost can be persistent due to the large amount of latent heat required to thaw the frozen ground as its temperature approaches $0^{\circ} \mathrm{C}$ (Romanovsky et al. 2010).

\subsection{Snow cover}

Reliable information on snow cover across the Arctic and sub-Arctic is needed for understanding the Arctic climate system and evaluating simulations of snow cover (and associated feedbacks) in climate models. Monitoring the key variables of snow water equivalent (SWE), snow cover extent (SCE) and snow cover duration (SCD) across the Arctic is complicated by strong local controls on snow cover, frequent cloud cover, and large gaps and biases in surface observing networks. Enhanced information on Arctic snow cover was acquired through Canadian IPY activities focused on the development of new algorithms to retrieve SWE from satellite passive microwave data, and the analysis of multiple sources of SCE and SWE information, including from satellite observations, atmospheric reanalysis, and surface measurements. This helped address uncertainties associated with individual datasets, and better understand connections between various snow cover variables.

Satellite passive microwave data are frequently used to retrieve terrestrial snow information because of frequency dependant relationships between microwave scatter and SWE. Typically, the brightness temperature difference is exploited between a frequency sensitive to snow cover $(\sim 37 \mathrm{GHz})$ and a frequency comparatively insensitive to snow $(\sim 19 \mathrm{GHz})$. The boreal forest cover across the sub-Arctic taiga and the highly heterogeneous distribution of Arctic snow cover tend to increase passive microwave SWE retrieval uncertainties when simple brightness temperature difference algorithms are applied. Further uncertainties are introduced by the vertically heterogeneous Arctic snowpack with dense, fine-grained wind slabs overlying loose large grained depth hoar, and by a high fraction of lakes which complicate microwave emission in some regions (Derksen et al. 2009). To develop new algorithms that address these challenges, three airborne campaigns were conducted across the Canadian sub-Arctic between February and April 2008 (see Derksen et al. 2010 and Langlois et al. 2011). The resulting measurements allowed better parameterization of radiative transfer properties of the taiga forest canopy, including the generation of new values for microwave transmissivity and single scattering albedo of the forest (Langlois et al. 2010, 2011). These new techniques for compensating for the effects of the forest layer have important implications for improving future satellite SWE retrievals because forested regions exhibit a high level of inter-dataset inconsistency in SWE patterns at the hemispheric 
scale (Clifford 2010), and state of the art SWE retrieval methods (such as Takala et al. 2011) still utilize relatively simplistic treatment of the forest canopy.

For tundra regions, the IPY airborne campaigns provided the necessary high resolution airborne measurements that, when combined with intensive field observations of snow distribution and physical properties, allowed development of the first tundra-specific passive microwave SWE retrieval algorithm (as described in Derksen et al. 2010). This new passive microwave derived SWE time series (derived from Special Sensor Microwave/Imager measurements) was one of four SWE datasets compiled for the 1980-2011 period. The other datasets were the satellite passive microwave algorithm described in Takala et al. (2011), the Canadian Meteorological Centre daily gridded global snow depth analysis (Brasnett 1999), and atmospheric reanalysis produced by the European Centre for Medium-Range Weather Forecasts (ERA-Interim; Dee et al. 2011). The use of multiple datasets allowed the statistical characterization of uncertainty in the standardized SWE anomaly time series following the method of Brown et al. (2010). The SWE anomaly time series is characterized by a high degree of inter-annual variability (Fig. 4a). In spite of documented positive trends in observed precipitation over high latitudes (Zhang et al. 2007; Mekis and Vincent 2011), there was no evidence of pan-Arctic SWE trends when these multiple datasets were considered.

Brown et al. (2010) described a new multi-dataset estimate of Arctic (land area north of $60^{\circ}$ excluding Greenland) monthly SCE for the May-June melt period derived from ten data sources covering different time periods from 1967 to 2008. The datasets included visible and microwave satellite observations, analyses of surface snow depth observations combined with a simple snow model, reconstructed snow cover from daily temperature and precipitation, and SCE estimates back-calculated from snow melt datasets. Trend analysis of the multi-dataset series (based on the monthly mean SCE values as described in Brown et al. 2010) revealed that May and June SCE have decreased by $14 \%$ and $46 \%$ respectively across the pan-Arctic over the 1967-2008 period in response to earlier snow melt. SCE anomalies (over the 1982-2008 period) from the recently released NOAA snow extent climate data record (CDR; see Brown and Robinson 2011) were significantly correlated with the datasets used in Brown et al. (2010), so the CDR record can be used to extend the Brown et al. (2010) time series beyond 2008. Northern Hemisphere spring SCE, for months when snow cover is confined largely to the Arctic, show increasingly negative trends as spring progresses (Figure S1), a tendency linked to a poleward increase in the sensitivity of SCE to warming air temperatures due to an enhanced snow-albedo feedback (Dery and Brown 2007).

Snow cover duration (SCD) anomalies (with respect to 1988-2007) computed separately for the first (fall; Fig. 4b) and second (spring; Fig. 4c) halves of the snow year using the weekly NOAA CDR provide information on changes in the start and end dates of snow cover. While the timing of snow cover onset (as captured by the fall SCD) shows little change over the satellite record, spring SCD anomalies (relative to the 1988-2007 reference period) exhibit a negative trend over the time series with a new record low spring SCD observed over both the North American and Eurasian sectors of the Arctic in 2010 (Fig. 4c).

Canadian IPY project teams also integrated observations with climate model simulations to improve understanding of snow-albedo feedback (SAF) processes (Fernandes et al. 2009), a critical determinant of the cryospheric forcing and response to the global climate system.

Fig. 4 a Time series of multi-dataset average April snow water equivalent (SWE) anomalies (standardized; +/- the standard error following Brown et al. 2010) for 1988-2010, relative to the 1988-2007 period for North America and Eurasia. Arctic seasonal snow cover duration (SCD) anomaly time series (with respect to 1988-2007) from the NOAA snow chart CDR for $\mathbf{b}$ the first (fall) and $\mathbf{c}$ second (spring) halves of the snow season. Smooth lines denote the 5-year running mean 

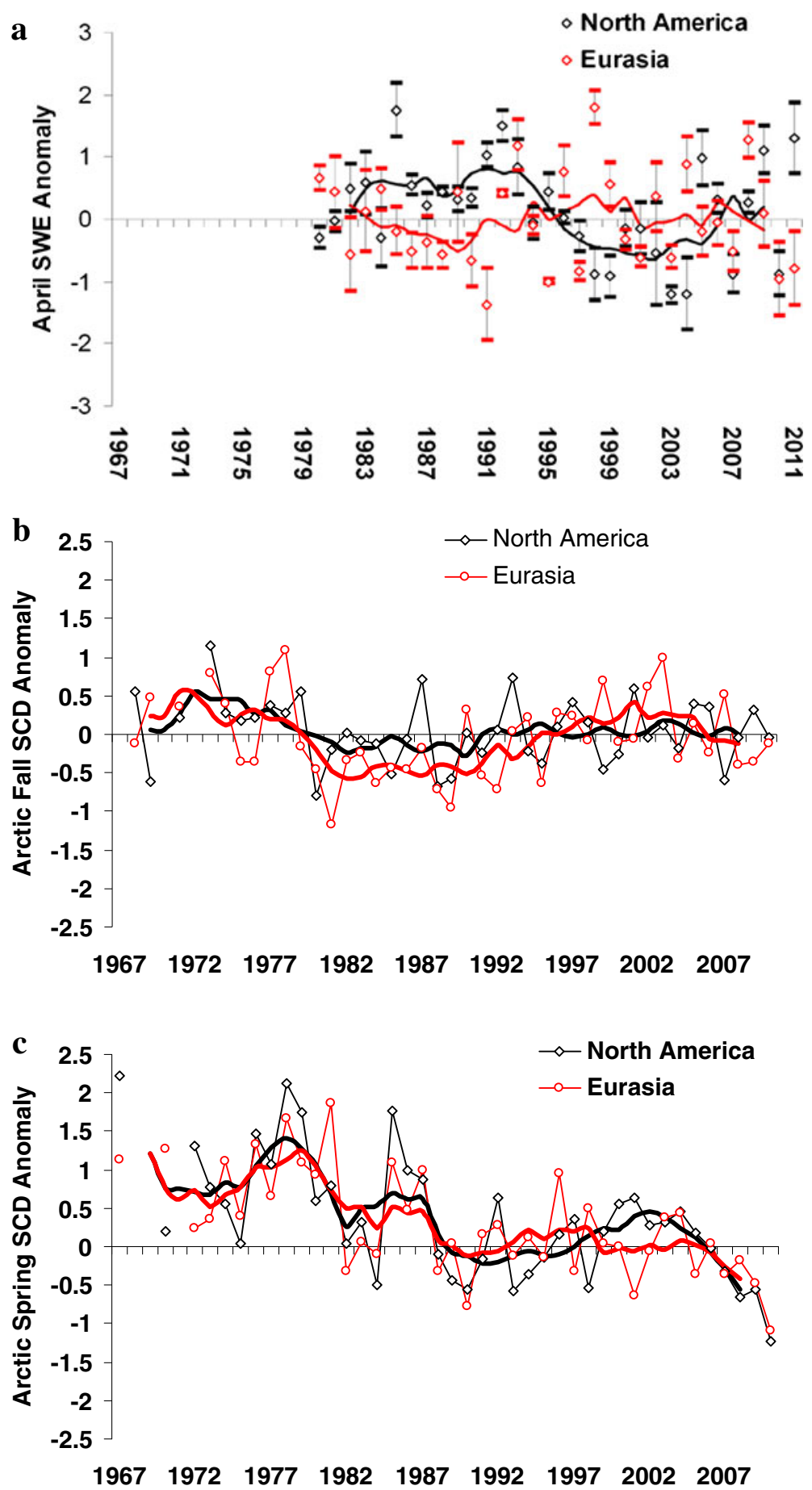
Climate model simulations showed the SAF to be associated with non-local atmospheric responses. For example, snow cover changes can induce circulation responses far removed from where the snow is located. Fletcher et al. (2009a) found that SAF strength explained, on average, $5-10 \%$ of the inter-model spread in climate change projections of NH sea level pressure and zonal-mean zonal wind. These results have initially been interpreted as the response to increased land-sea contrasts in models with stronger SAF. In the present-day seasonal cycle, fall season snow cover variations over Eurasia are associated with surface shortwave forcing that can affect wintertime atmospheric variability over much of the northern hemisphere (e.g., Cohen and Entekhabi 1999). Improved understanding of the dynamical mechanisms responsible for this link (Fletcher et al. 2009b; Smith et al. 2010a; Hardiman et al. 2008), could yield future improvements in the accuracy of seasonal-todecadal climate prediction.

\subsection{Sea ice}

There have been dramatic changes in Arctic sea ice cover during the past decade. The once dominant multi-year ice (MYI) in the Arctic Ocean has been largely replaced by seasonal first-year ice (FYI) (Maslanik et al. 2007). Mean winter ice thickness over the Arctic Ocean is now nearly $50 \%$ less than 1980 values (Kwok and Rothrock 2009). A record low Arctic sea ice extent of $4.28 \times 10^{6} \mathrm{~km}^{2}$ was observed in September 2007 (approximately $39 \%$ below the 1979 to 2000 climatological mean extent; Stroeve et al. 2008). While the 2007 melt season remains the record low ice extent for the pan-Arctic, subsequent summer seasons were also characterized by minimum ice extent well below the mean (Stroeve et al. 2011). Sea ice extent decreases are no longer confined to the summer months, and are now occurring in the once stable winter months (Comiso 2006; Serreze et al. 2007).

While the recent Arctic-wide changes in sea ice extent and character are indeed dramatic, there still is considerable regional variability. Understanding this variability is vital to projecting the response of the Arctic climate system to future change. The Canadian Arctic Archipelago (CAA) is of particular importance due to the implications of a seasonally ice free Northwest Passage for regional climate, maritime activities, and security. To investigate this long-term variability, sea ice conditions within Canadian Arctic waters were examined with the Canadian Ice Service Digital Archive (CISDA), an integration of remotely sensed data, surface observations, airborne and ship reports, operational model results and the expertise of ice analysts (Tivy et al. 2011a). The CISDA extends back to 1960 for some regions of the Canadian Arctic, almost 20 years longer than covered by satellite passive microwave observations. Complete and reliable coverage of all Canadian Arctic regions, however, begins in 1968. Tivy et al. (2011a) used the CISDA to document recent summer sea ice trends and variability within Canadian Arctic waters from 1968 to 2008, and here this analysis is updated through 2010. The summer ice season is taken as June 25 to October 15 for Canadian Arctic regions (i.e. Southern Beaufort Sea, CAA, Baffin Bay, Kane Basin and Foxe Basin) and as June 18 to November 19 for Hudson Bay regions (i.e. Hudson Bay, Hudson Strait, Davis Strait and Northern Labrador Sea).

Between 1968 and 2010 total sea ice cover, averaged over the summer period, decreased approximately 3 to $17 \%$ per decade depending on the region (Fig. 5). Tivy et al. (2011a) found that these long-term summer sea ice decreases are forced by increases in spring air temperature, which explain up to $58 \%$ of the inter-annual variability. For summer MYI only the southern Beaufort Sea and Foxe Basin exhibited significant decreases of $16 \%$ and $20 \%$ decade $^{-1}$ respectively (Fig. 5). The lack of significant decreases in MYI within the CAA has 


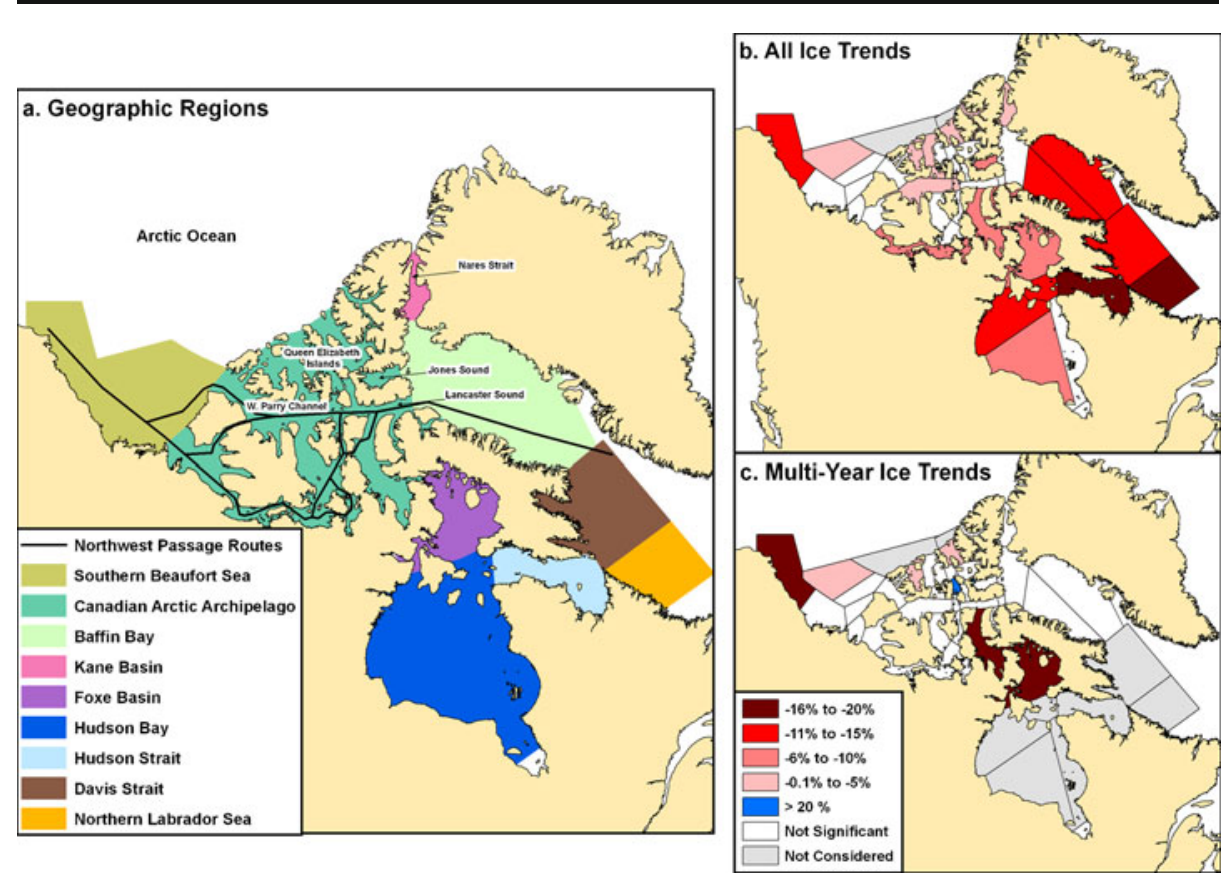

Fig. 5 Sea ice regions of the Canadian Arctic a with corresponding trends in summer total sea ice area b and multi-year sea ice area c from 1968 to 2010; units are \% decade ${ }^{-1}$. Only trends significant to the $95 \%$ confidence level are shown [Updated from Tivy et al. 2011a]

been attributed to increased dynamic MYI import from the Arctic Ocean that replaces ice lost due to melt (Howell et al. 2009a).

The time series of sea ice area for the Southern Beaufort Sea and the CAA show considerable inter-annual variability, with extreme minima occurring in 1998 and in the IPY years of 2007 and 2008 (Fig. 6a and b). Within Baffin Bay there is also considerable inter-annual variability in summer sea ice area since 1968, although the last decade is characterized by consistent low ice years, with the lowest ice area occurring in 2007 (Fig. 6c). The time series for Hudson Bay is characterized by a shift toward lighter ice conditions in the mid- to late 1990's (potentially linked to a cold to-warm phase shift in the Atlantic Multi-decadal Oscillation as described in Tivy et al. (2011b)) that have persisted through 2010, the lowest ice year since 1968 (Fig. 6d). Hudson Bay sea ice has also undergone a shift toward reduced sea ice area during the fall months since the 1990s. Hochheim and Barber (2010) investigated fall (October and November) sea ice area trends in Hudson Bay from 1980 to 2005 and found large decreases ranging from $23.3 \%$ to $26.9 \%$ decade ${ }^{-1}$.

A significant sea ice event during the IPY was the 2007 clearing of the Northwest Passage route through the western Parry Channel for the first time in the satellite era. The mechanism responsible was prior thinning of the MYI, followed by rapid melt, and most importantly, an atmospheric circulation pattern that prevented MYI from the Queen Elizabeth Islands (QEI) from entering the Western Parry Channel (Howell et al. 2009a). Subsequent low ice years also occurred in 2008 and 2010, and there is evidence that a similar event likely occurred outside the satellite era in 1962 (Tivy et al. 2011a). Despite these low ice years, MYI continues to be transported southward from the QEI into the Northwest Passage posing a 

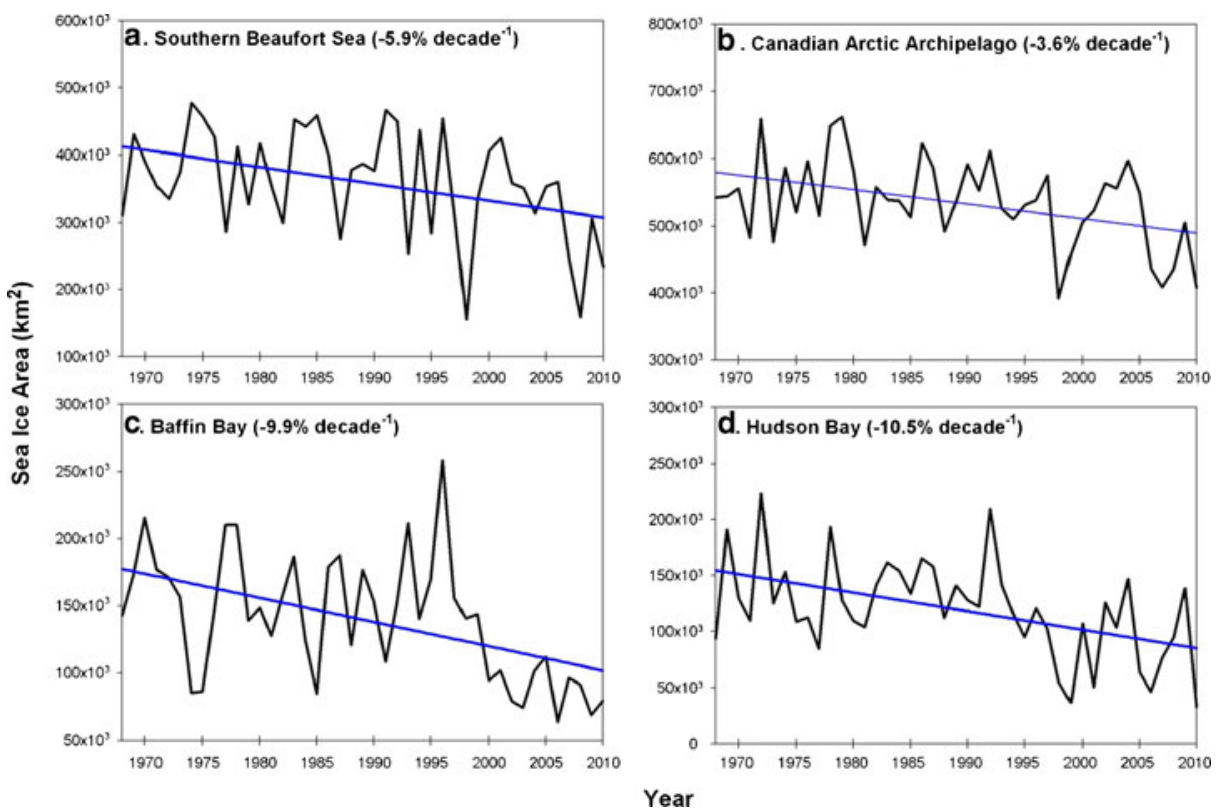

Fig. 6 Time series of summer total sea ice area for the Beaufort Sea (a), Canadian Arctic Archipelago (b), Baffin Bay (c), and Hudson Bay (d) regions from 1968 to 2010 [Updated from Tivy et al. 2011a]

serious threat to shipping. Even as Arctic temperatures continue to increase (Kaufman et al. 2009) and the melt season continues to lengthen (Markus et al. 2009), clearing of the Northwest Passage is also sensitive to wind direction, which can either transport MYI southward from the QEI or inhibit ice advection into the Passage. This is in agreement with the suggestion of Melling (2002) that MYI will still be supplied to the Western Parry Channel region of the Northwest Passage under a warming climate. Model predictions also indicate this region will be unlikely to consistently allow summertime shipping even when the Arctic Ocean is predominantly ice-free (Sou and Flato 2009; Stephenson et al. 2011).

\subsection{Lake and river ice}

Lake ice cover both forces and responds to climate variability. Trends in ice phenology records (break-up/freeze-up dates) tend to be linked with variations in air temperature, while trends in ice thickness are associated with both temperature and snow cover (see Brown and Duguay 2010). During previous decades, changes in lake ice cover were monitored with ground based observations; however, the transition from manned to automated climate stations in Canada has greatly diminished this network (Lenormand et al. 2002). To address the resulting observing gap, IPY activities in Canada contributed to developing both remote sensing and modeling-based solutions to monitoring lake ice throughout Canada.

Ice-on/off dates for large lakes can be determined from active and passive microwave imagery (e.g. Howell et al. 2009b), but obtaining ice thickness estimates from satellite measurements is more challenging. Progress was made by Kang et al. (2010) who showed the potential for using passive microwave brightness temperatures for estimating ice thickness on large northern lakes. 
Lake ice models can be used to assess potential changes to ice cover using projected climate conditions. Brown and Duguay (2011) produced both contemporary and future ice cover information (1961-2100) for areas above $58^{\circ} \mathrm{N}$, using 1-D simulations with the Canadian Lake Ice Model (CLIMo) driven by the Canadian Regional Climate Model (IPCC SRES A2). Since snow cover plays an important role in the seasonal evolution of lake and river ice, simulations were run with both a full snow cover and no snow cover on the ice to assess the effects of wind redistribution. Simulations show that nearly all of Arctic North America is predicted to experience an advance in mean break-up dates in the range of 525 days from 1961-90 to 2041-70 (with a mean difference of 7 days between snow-free (later) and snow-covered lakes (earlier)), while freeze-up is predicted to occur up to 15 days later (Fig. 7). These results are comparable to those identified by Dibike et al. (2011) for future changes in lake ice over North America produced with a different lake ice model. The lake ice projections for break-up/freeze-up were more sensitive to air temperature changes, while the simulated ice thickness is more sensitive to changes in snow cover amount (Brown and Duguay 2010). Both future climate scenarios produced a drastic reduction in the areas in which occasional summer or perennial ice cover is found. The maximum ice thickness was predicted to decrease by an average of $21 \mathrm{~cm}$ for the snow simulations and $28 \mathrm{~cm}$ for the snow-free simulations from 1961-90 to 2041-70, with areas of maximum loss exceeding $40 \mathrm{~cm}$ in parts of Alaska.

These projected changes in ice cover will affect the role of lakes in energy, water and biogeochemical processes in cold regions, and result in ecosystem changes within the lakes. A shorter ice covered season will have a detrimental effect on the duration and stability of winter ice roads in northern Canada, which affects overland access to regions of northern development (Furgal and Prowse 2008). Increased travel risk linked to freshwater ice instability and weather unpredictability is also an important issue for northern communities (Lafortune et al. 2004) which typically rely on trail networks on freshwater ice. Assessing the scope and impact of such changes requires extended and continuous research and monitoring. Traditional knowledge, local observations, and field measurements were used by Tremblay et al. (2008) to assess changes in ice conditions at locations along key trails in Nunavik (northern Quebec). This community-driven information successfully reduced travel risks, while facilitating inter-community information exchange on a changing environment.

A practical solution to monitoring freshwater ice on a larger scale is to combine satellite imagery and local knowledge of ice conditions. One IPY study examined the potential to use remote sensing as part of an ice monitoring program (Gauthier et al. 2010) with the town of Kuujjuaq, located inland along the Koksoak River, chosen as the experimental site. A river ice classification algorithm was refined based on an unsupervised fuzzy K-mean classification of Radarsat imagery (Gauthier et al. 2010), and river ice maps were provided to the community as a tool for planning safer travel in the region. During the 2 years of the project, maps were produced every 7-10 days (Figure S2) and made available to the population (website and paper copies) within $36 \mathrm{~h}$. Calibration and validation of the river ice maps consisted of aerial surveys, ground observations, photos, and field measurements.

\subsection{Land ice}

Research on Arctic glaciers and ice caps during the IPY focused on two main themes. First, documenting recent changes in the glacier extent, volume, and mass over the period since the 1957/58 International Geophysical Year (IGY), relating them to changes in climate over the same period, and (where possible) placing them in a longer-term context. Second, investigating the role of changes in ice flow dynamics in the response of Arctic ice caps 


\section{No snow cover}

a) Break-up

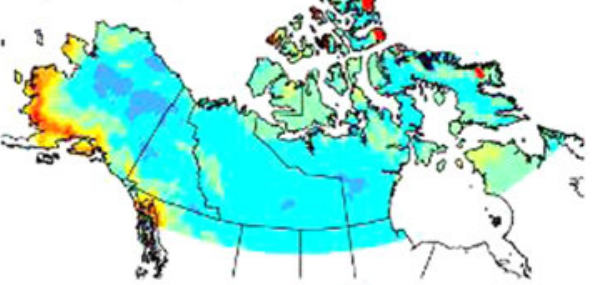

b) Freeze-up

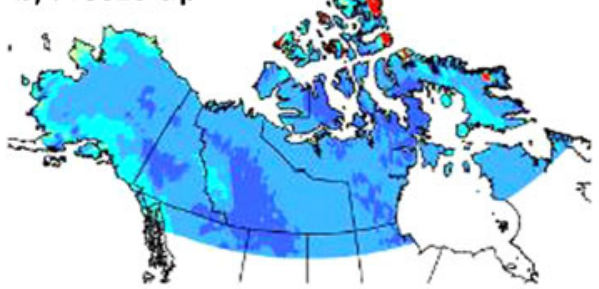

Full snow cover
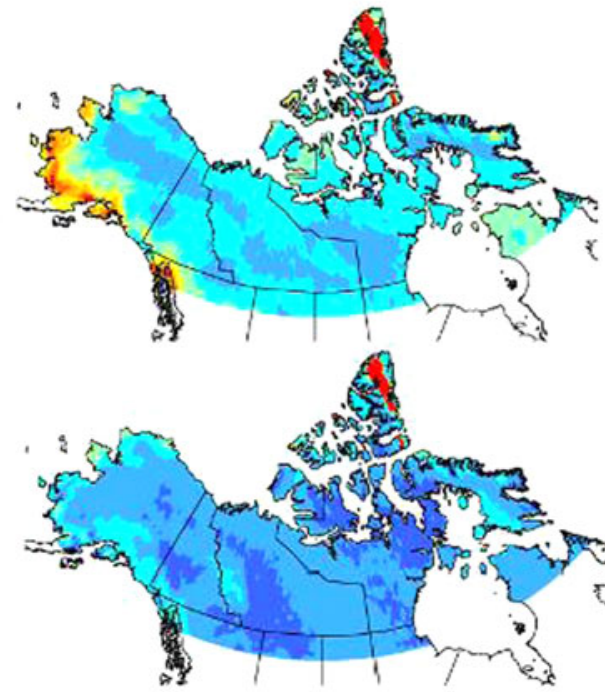

Change in mean break-up date (days earlier)/freeze-up date (days later), 1961-1990 mean to 2041-2070 mean

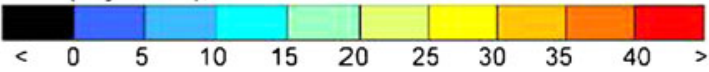

c) Maximum ice thickness

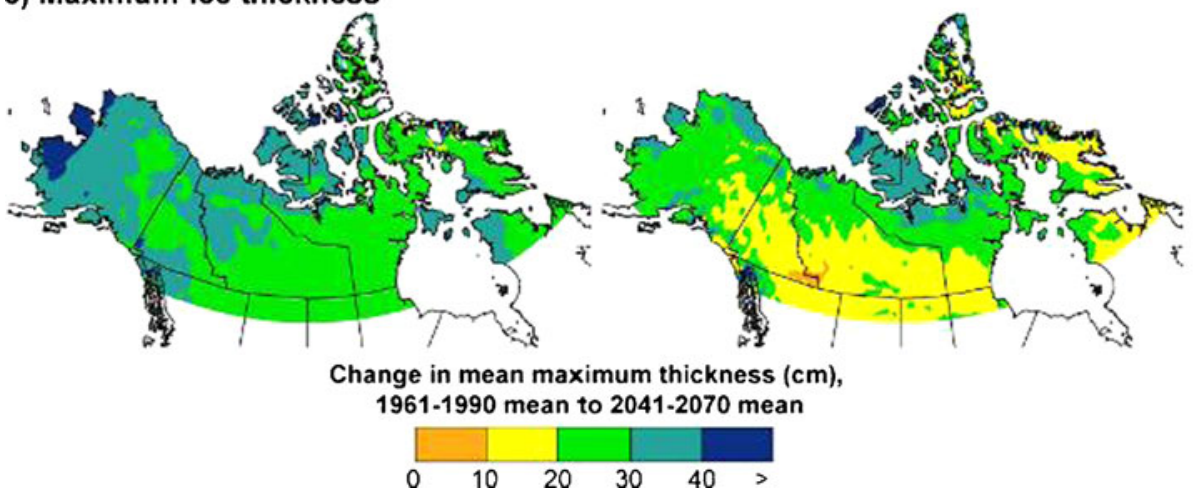

Fig. 7 Predicted changes to the ice cover on hypothetical $10 \mathrm{~m}$ deep lakes from the 1961-90 mean to the 2041-70 mean for a break-up date, b freeze-up date and $\mathbf{c}$ maximum ice thickness (positive values indicate reductions in ice thickness) using CLIMo driven by projected climate data from the CRCM. Areas of $>40$ days change in the far north represent a loss of perennial ice cover and these areas are excluded from the thickness change maps (modified from Brown and Duguay 2011)

to climate change. Studies on the trends and levels of atmospheric contaminant deposition on Arctic ice caps were also undertaken during the IPY but are beyond the scope of this review.

New studies of glacier area change were initiated in the Yukon (Barrand and Sharp 2010) and Labrador, in situ measurements of glacier mass balance continued on 4 glaciers in the QEI (Devon Ice Cap, Meighen Ice Cap, Melville South Ice Cap and White Glacier; Sharp et al. 2011), and a regional scale study of glacier mass change since 2003 in the QEI, Bylot Island and Baffin Island was completed (Gardner et al. 2011). In addition, climate data from 
Environment Canada weather stations, automatic weather stations on the Devon and Agassiz ice caps, and remotely sensed measurements of ice surface temperature (from Moderate Resolution Imaging Spectroradiometer - MODIS) and melt season duration (for the period 2000-2009; retrieved from the SeaWinds scatterometer on QuikSCAT) were used to document changing melt conditions on ice caps in the QEI (Sharp et al. 2011) and Baffin Island (Sharp and Wolken 2011). New ice cores and deep snowpits were collected/measured on those ice caps from which deep ice cores had previously been extracted in order to extend the climate records from these sites to the present day (Fisher et al. 2012).

Changes in the surface area of Yukon glaciers during the 50 years since IGY were assessed via comparison of glacier extents on historical topographic maps and aerial photographs with those derived from recent LandSat7 imagery (Barrand and Sharp 2010). Results showed that glaciers in this region lost $22 \%$ of their surface area (a total loss of 2,541 $189 \mathrm{~km}^{2}$ ) over the 50 year period, representing a total mass loss of $406 \pm 177 \mathrm{Gt}$ (equivalent to $1.13 \pm 0.49 \mathrm{~mm}$ of global sea level rise). Comparison with data from Environment Canada weather stations and the NCEP/NCAR R1 re-analysis indicated that these changes in glacier mass and surface area were coincident with general summer warming (since 1970) and reductions in winter precipitation over the period of record (Barrand and Sharp 2010).

In the QEI, in situ measurements have shown that year-to-year variability in glacier mass balance is driven largely by changes in summer climate and mass balance (Koerner 2005). These measurements, initiated in late 1950s/early 1960s, reveal a strong shift towards more negative balances since 2005 (30-48 \% of the total mass loss since 1963 has occurred since 2005). This corresponds to an increase in summer surface air temperatures of $0.8^{\circ} \mathrm{C}$ to $2.2^{\circ} \mathrm{C}$ in 2005-2009 relative to 2000-2004 and an associated increase in melt season length of 4.7 to 11.9 days. Averaging measurements for the 4 glaciers monitored, the IPY years of 2007, 2008 and 2009 had the three most negative balances in the period of record (2007 and 2008 were two of the five warmest summers since 1948). The mean rate of mass loss from 2005 to 2009 was nearly five times greater than the mean rate for 1963-2004 (Sharp et al. 2011). Strong atmospheric heat advection in summer into the QEI via Davis Strait and Baffin Bay from a region of anomalously positive sea surface temperatures in the northwest Atlantic seems to have been responsible for the climate warming that resulted in these very negative mass balances (Figure S3; Sharp and Wolken 2011).

New studies of melt layer frequencies in ice and firn cores and snow pits from the Canadian Arctic ice caps indicate that melt rates in the last few decades have been uniquely high in the context of the last 4000 years. Since the early 1990s, melt rates are similar to those during the early Holocene thermal maximum (Fig. 8; Fisher et al. 2012). This is despite the fact that incident solar radiation in northern high latitudes in summer continues to decrease from the high values that characterized the early Holocene (Kaufman et al. 2009).

At a regional scale, independent geophysical measurements based on ICESat (Ice, Cloud, and land Elevation Satellite) laser altimetry, and GRACE (Gravity Recovery and Climate Experiment) satellite gravimetry indicate that glaciers and ice caps in the CAA lost mass at a mean rate of $61 \pm 7 \mathrm{Gt}$ per year from 2004 to 2009 , equivalent to a total rise in global mean sea level over the period of $1.01 \pm 0.11 \mathrm{~mm}$ (Gardner et al. 2011). The mean rate of mass loss jumped from $31 \pm 8 \mathrm{Gt}$ per year from 2004-2006 to 92 \pm 12 Gt per year from 2007 to 2009 . The CAA was likely the single largest regional contributor to eustatic sea-level rise outside Greenland and Antarctica during this latter period. About $61 \%$ of the mass loss came from the QEI, and about $92 \%$ was in the form of meltwater runoff (as opposed to iceberg calving) (Gardner et al. 2011).

The Canadian contribution to the IPY project Glaciodyn focused on the Belcher Glacier, the largest tidewater glacier draining from the Devon Ice Cap, Nunavut. The goal of this 


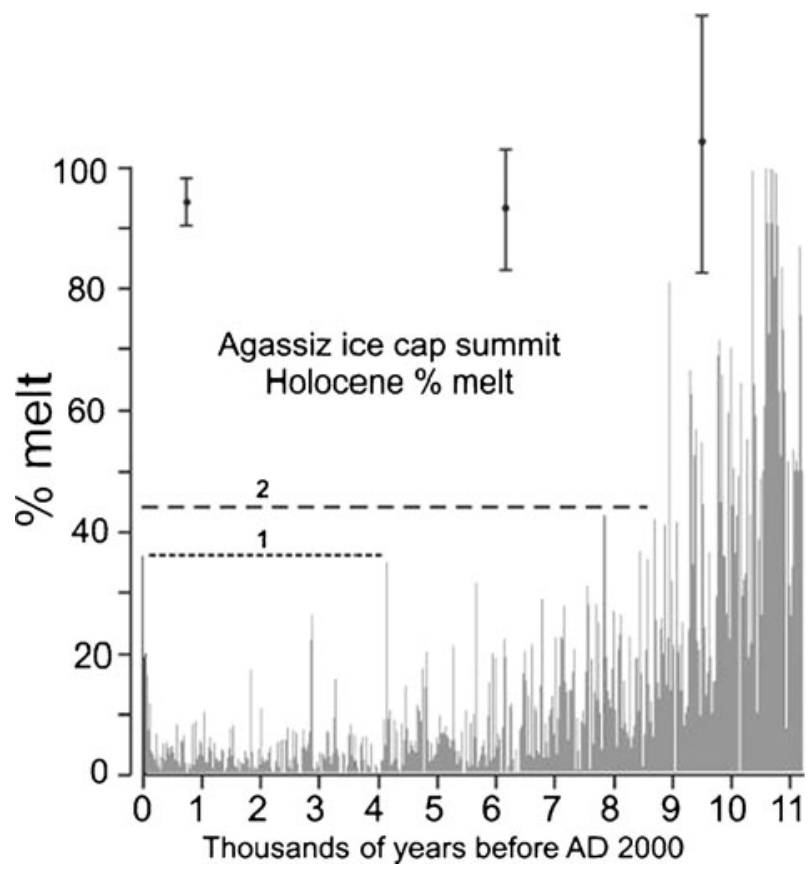

Fig. 8 The Holocene summer melt record (25 year averages) from the Agassiz Ice Cap, Ellesmere Island. The record is based on the melt feature percentages of two ice cores drilled in 1984 and 1987, and firn cores recovered at the site in the spring of 2009. The estimates of error come from the rms value of the differences between the 1984 and 1987 melt feature series. The melt rate for the most recent 25 years is the highest since the mid-Holocene (line 1). Since the early 1990s melt rates have been approaching levels not seen since the early Holocene (line 2), over 9000 years ago (From Fisher et al. 2012)

project was to develop and validate a new coupled model of glacier hydrology and glacier flow (Pimentel and Flowers 2010; Pimentel et al. 2010) and to use it to explore how Belcher Glacier would respond to changes in atmospheric and oceanic forcing. Field programs, that included mapping of surface and bedrock topography and monitoring glacier flow with continuously recording GPS, were conducted on Belcher Glacier in the summers of 2007 through 2009. Iceberg calving was monitored with time lapse photography, acoustic and passive seismic monitoring systems, while offshore bathymetry and water column properties were also determined. Remote sensing activities concentrated on repeat mapping of the surface velocity field of the Devon Ice Cap, including the Belcher Glacier (Van Wychen 2010), providing context for the point velocity measurements made using GPS sensors.

A distributed energy balance based model of glacier surface melt and snowpack evolution was used to simulate the daily production of surface meltwater across the glacier in the summers of 2008 and 2009 (Duncan 2011). This model was applied to individual sub-catchments on the glacier surface to generate daily runoff time series that could be compared with time series of lake-filling/drainage, glacier surface velocity, proglacial meltwater plume extent, and iceberg calving events. Preliminary experiments demonstrate that the model can simulate seasonal evolution in the character of the subglacial drainage system, glacier velocity response to seasonal and diurnal changes in rate of meltwater delivery to the glacier bed, and short-lived changes in glacier velocity driven by the drainage of supraglacial lakes. All of these 
behaviours are apparent in the GPS-derived velocity datasets collected from Belcher Glacier.

\subsection{Ice shelves}

The ice shelves along the northern coast of Ellesmere Island are relics of climate cooling that occurred about 5500 years ago (England et al. 2008). They formed through in situ growth of sea ice (surface snow accumulation and basal freeze on), while some also received input from glaciers that formed on northern Ellesmere Island (England et al. 2008; Jeffries 2002). Much of the $90 \%$ decrease in ice shelf extent that has occurred since their discovery in the late 19th century coincided with a period of regional warming in the 1930s and '40s. Marked positive air temperature anomalies since the 1990s have driven further ice shelf collapse (Copland et al. 2007). The complete loss of the Ayles Ice Shelf (about $87 \mathrm{~km}^{2}$ ) in 2005 was accompanied by the loss of about $1020 \mathrm{~km}^{2}$ of multiyear landfast sea ice (MLSI) in nearby Yelverton Bay (Copland et al. 2007). MLSI typically fringed the fronts of ice shelves in the past and protected them from the open ocean, and can be considered as incipient ice shelf (Pope et al. 2012). The loss of MLSI may therefore limit the potential for ice shelf regrowth under current climate conditions, and make the ice shelves more vulnerable to future climate change (Copland et al. 2007).

A Canadian Rangers traverse (described previously) measured the thickness of the Milne, Petersen, and Serson ice shelves with ground penetrating radar. Typical thicknesses for the three ice shelves were 40-90 m (maximum $94 \mathrm{~m}$ ), 40-65 m (maximum $65 \mathrm{~m}$ ) and 30-40 m (maximum $63 \mathrm{~m}$ ), respectively. This was the first time that the thickness of the Serson and Petersen ice shelves had been measured. Milne Ice Shelf thickness decreased by an average of $8.0 \pm 2.4 \mathrm{~m}$ (a total volume loss of $\sim 16 \%$ ) since it was first measured in 1981 (Mortimer et al., in review). An extensive network of new cracks on the eastern Ward Hunt Ice Shelf was documented and mapped by the Rangers in April 2008. The following summer several large tabular 'ice islands' totalling approximately $40 \mathrm{~km}^{2}$ broke off from the Ward Hunt Ice Shelf (Fig. 9). This was followed in the same year by the loss of the entire Markham Ice Shelf $\left(\sim 50 \mathrm{~km}^{2}\right)$ and $60 \%\left(120 \mathrm{~km}^{2}\right)$ of the Serson Ice Shelf (Mueller et al. 2008; Vincent et al. 2009). By the end of summer 2008, the total area of the remaining Ellesmere Island ice shelves had reached a new record low of $720 \mathrm{~km}^{2}$ (Mueller et al. 2008).

\section{Discussion}

\subsection{The cryosphere as an integrated system}

The various components of the cryosphere are often investigated as distinct entities in climate studies because of traditional boundaries between sub-disciplines, the various noncomplementary datasets used to examine each component, and the challenges in conducting unified field campaigns that span multiple elements of the cryosphere. However, awareness of the interconnected nature of the cryosphere, and the integrated role it plays in the global climate system, is increasing (for example, Francis et al. 2009; Rawlins et al. 2010). In this context, it is important to identify evidence of consistent responses across the cryosphere to climate variability and change, as well as the relationships between components of the cryosphere.

The observed changes in the Canadian cryosphere during the IPY period are consistent with trends identified in previous decades (e.g. Serreze et al. 2000; Atkinson et al. 2006), 

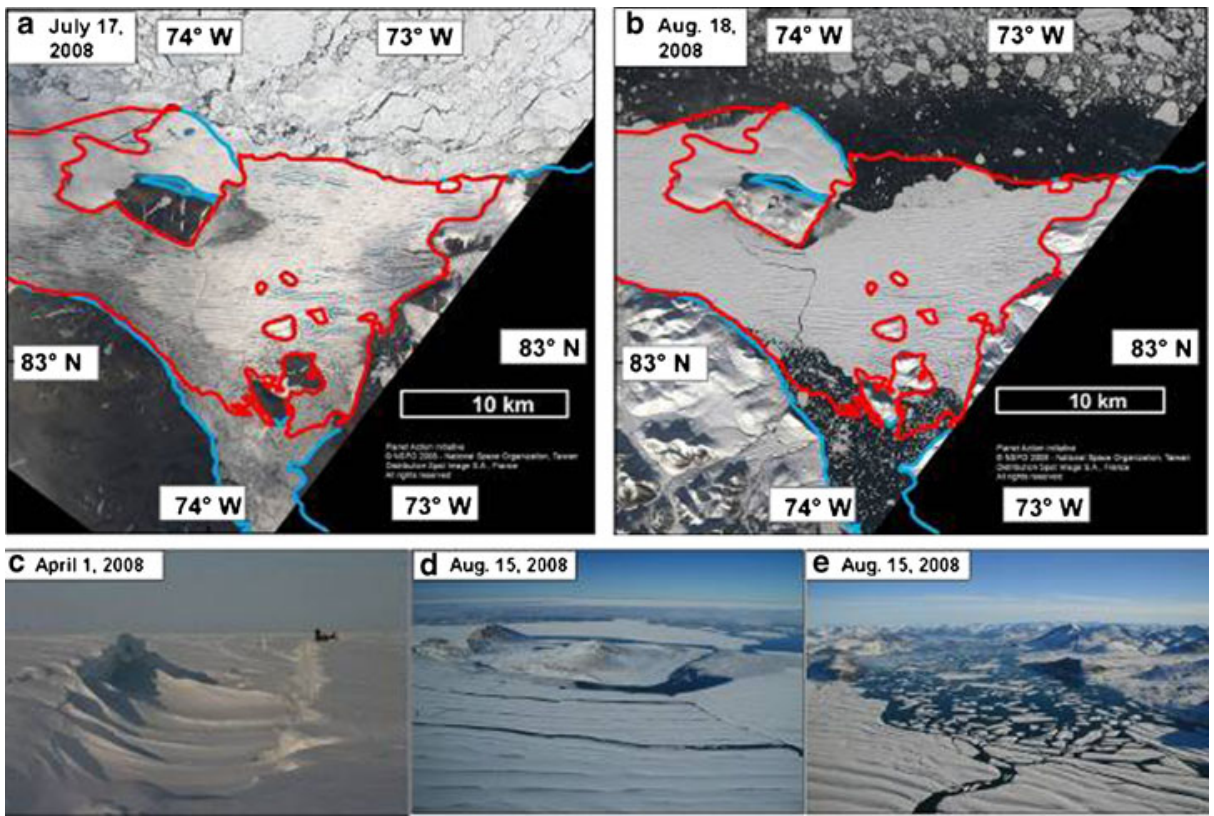

Fig. 9 a and b Formosat-2 images at the start and of summer 2008 (original ice shelf outlined in red). 2008 area loss was $\sim 42 \mathrm{~km}^{2}$, with a further $>50 \mathrm{~km}^{2}$ lost in August 2010 (not shown); c Large crack on ice shelf in spring 2008; d Aerial view of front of the ice shelf during disintegration; e Aerial view of rear of the ice shelf during disintegration: note extensive calving into the fiord behind. Formosat imagery courtesy of Pax Arctica and the Planet Action Initiative, (C) NSPO 2008-National Space Organization, Taiwan, Distribution Spot Image S.A., France, All rights reserved. Photographs courtesy of Cpl Doug Stern, Canadian Rangers (spring 2008) and Warwick Vincent, Université Laval (summer 2008)

with increases in surface and lower tropospheric air temperatures the likely primary drivers of these changes. The observed changes are consistent with warming surface temperatures (Fig. 2), in that they all indicate a reduction in the spatial extent and mass of the cryosphere (such as sea ice area/volume and negative glacier mass balance) as well as an increase in the temporal persistence of melt related parameters (i.e. shorter terrestrial snow cover duration; longer glacier melt seasons). Observed changes also include warming of permafrost, reductions in spring snow cover extent, reductions in summer sea ice extent including multi-year ice area, and dramatic ice loss events for ice shelves along the north coast of Ellesmere Island.

In many cases, rates of observed cryospheric changes during the IPY period increased relative to pre-IPY conditions. For instance, observed increases in shallow (15 m depth) permafrost temperature at Alert since the 1990s, including an increase in the rate of warming since 2005 (Fig. 3c; also see Smith et al. 2010b and Throop et al. 2010), were likely driven by positive air temperature anomalies. Arctic snow cover extent exhibits decadal scale reductions since the mid-1960's, with the start of the 21 st century marking dramatic reductions to record lows in 2008 and 2010 (Fig. 4; Figure S1). Increasing mass loss for high Arctic glaciers has been observed since the 1990s but is particularly dramatic since 2005 (e.g. Allison et al. 2011; Sharp and Wolken 2010). Decreases in sea ice area, particularly in the summer, are evident across the Canadian Arctic, and are highlighted by extreme events (Howell et al. 2010; Tivy et al. 2011a). Rapid and extreme ice loss events have also affected the northern Ellesmere ice shelves, particularly in the summer of 2008 
when large ice islands $\left(\sim 40 \mathrm{~km}^{2}\right)$ broke off the Ward Hunt Ice Shelf, while the entire Markham Ice Shelf $\left(\sim 50 \mathrm{~km}^{2}\right)$ and $60 \%\left(\sim 120 \mathrm{~km}^{2}\right)$ of the Serson Ice Shelf were lost.

While many changes in cryospheric components can be linked to warm temperature anomalies, this is not the only forcing element to consider. In the case of CAA sea ice, it is important to distinguish between dynamic and thermodynamic influences on ice anomalies. Over the past 41 years, summer sea ice conditions in the CAA during 1998 and 2007 stand out as extreme low ice years, but the forcing mechanisms during these two seasons were distinct, with temperature anomalies providing only a partial explanation. As described in Howell et al. (2010), persistent high sea level pressure over Greenland in 1998 was coupled with low pressure over Hudson Bay during most of the melt season. This pattern allowed predominantly warm air masses of southerly origin to flow over the CAA, facilitating anomalously warm temperatures and an extended melt season that ablated the thicker MYI. This atmospheric circulation pattern also restricted sea ice import from the Arctic Ocean into the CAA. The sea ice in the southern Beaufort Sea was also influenced by this circulation regime, which in combination with low sea ice cover in the autumn of 1997 , contributed to the 1998 extreme minima. In 2007, anomalously warm temperatures in July facilitated an intense rapid melt which led to extreme low ice conditions within the CAA. However, high sea level pressure over the Beaufort Sea drove the advection of sea ice away from the Eurasian sector of the Arctic Ocean towards and into the CAA, facilitating the dynamic import of MYI and thus preventing 2007 from eclipsing the 1998 record ice loss. These two low ice seasons illustrate the importance of sea ice dynamics, driven by atmospheric circulation, which can facilitate ice export and/or replenishment within the CAA during the summer melt season.

Quantifying linkages in the variability between cryospheric elements is challenging because of different spatial and temporal response scales (for instance, terrestrial snow can undergo complete seasonal melt in a matter of days, while glaciers respond over periods of years to decades), and the potential for long time lags between forcing events. The panArctic, pan-cryosphere response to spring temperature anomalies was explored in an integrated manner by Wang et al. (2011) who showed that the melt onset date across the Arctic mainland was significantly correlated with both July and August sea ice extent. Correlation analysis showed that both July and August sea ice extent exhibited significant negative correlations with spring (AMJ) air temperatures ( $\mathrm{r}=-0.63$ for both months), while sea ice extent in other months was not significantly correlated with spring air temperatures. This suggests that spring air temperature anomalies are the main mechanism for the significant relationships between melt onset on land and sea ice extent. This interpretation is consistent with the findings of Brown et al. (2010) who found that observed reductions in June SCE over the 1979-2008 period were of the same magnitude as reductions in June sea ice extent with both series significantly correlated to air temperature changes over the Arctic region. These results underscore the close relationship between the cryosphere and surface air temperatures over the Arctic region in June when albedo feedback potential is at a maximum.

Changes in the cryosphere can have significant ecological consequences. With respect to terrestrial ecosystems, snow cover, permafrost conditions, surface hydrology, and vegetation are all inter-related. For example, recent dramatic reductions in Arctic spring snow cover duration reported in Brown et al. (2010) and Derksen and Brown (2011) have direct effects on wildlife (for example, see Drever et al. 2011). Shorter snow cover seasons are consistent with an extension of the growing season over the Arctic as discussed in Jia et al. (2009), and are consistent with earlier peak stream flow, a more rapid recessional limb, and higher peak runoff volume, as reported by Shiklomanov and Lammers (2009). 
Thawing of ice-rich permafrost leads to ground settlement and collapse, ponding of water (thermokarst) and a conversion of forested ecosytems to sedge wetlands and fens (Smith et al. 2008; Vallée and Payette 2007; Payette et al. 2004; Thibault and Payette 2009). Changes in subsurface conditions can also lead to land instability in permafrost regions. Rapid and deep active layer formation associated with warmer summer temperatures can result in active layer detachments, as were observed on Melville Island in summer 2007 (Lamoureux and Lafrenière 2009). Increases in thaw slumping around lakes has been observed in the Mackenzie Delta region over the last 50 years, and likely results from the thawing of permafrost due to warming air temperatures and thermal disturbance associated with slump-induced removal of vegetation (Lantz and Kokelj 2008; Kokelj et al. 2009a). Thermokarst processes, lake expansion, and slope instability can also result in changes to sediment loads and water chemistry which may have implications for aquatic ecosystems (Kokelj et al. 2009b; Lamoureux and Lafrenière 2009; Dugan et al. 2009). Changes in terrestrial ecosystems may also result from the surface disturbance and redistribution of soil through alterations of microbial activity and availability of nutrients (Pautler et al. 2010; Lantz et al. 2009). The impacts of cryosphere changes on terrestrial and marine ecosystems are discussed in other papers of this volume.

\subsection{Implications of a changing cryosphere for human activity in the North}

A change to ice cover (both freshwater and marine) will affect northerners through impacts on wildlife, marine resources, infrastructure, transportation, nutrition, and safety. There are also implications for natural resource development as ice roads provide essential access to exploration sites and allow the re-supply of mineral and hydrocarbon production sites (Prowse et al. 2009; Furgal and Prowse 2008). Delayed freeze-up and earlier break-up of lake and river ice mean that mines in the Slave Province of the Northwest Territories that depend on ice roads will be faced with shorter operating periods to transport supplies to mine sites. Adaptation options, such as the construction of all season roads, may need to be considered (Prowse et al. 2009). Many northern communities depend on rivers and lakes for travel and hunting activities that will be impacted by changing climate. As demonstrated during IPY, community travel route and ice monitoring programs along with satellite measurements can be utilized as an effective tool for producing information on river ice status for use at the local level and at larger scales.

Changes to ground thermal conditions including warming and thawing of permafrost can result in changes to the engineering properties and strength of the ground which have implications for infrastructure performance. Although the impacts of construction and operation on ground thermal conditions are usually incorporated into engineering design, climate change presents an additional challenge which needs to be considered to ensure integrity over the operating life of northern infrastructure (e.g. Smith et al. 2001). Incorporation of climate change into engineering design becomes particularly important for infrastructure that must maintain its integrity over several years, or where the consequences of failure is high, such as for waste containment structures (Prowse et al. 2009). The development of guidelines for climate change adaptation with respect to infrastructure on permafrost (Canadian Standards Association 2010) has benefited from the increased knowledge of permafrost conditions generated through Canadian IPY activities. The increased availability of up to date information supports the needs of engineers for the design of community infrastructure (e.g. Ednie and Smith 2011) and large scale resource development projects as proposed for the Mackenzie Valley (e.g. Smith et al. 2009). 
4.3 International Polar Year: a legacy of collaboration and innovation

In addition to driving scientific innovation, IPY investment in cryospheric research in Canada produced a number of other impacts. These include:

New and/or enhanced observing networks: Through IPY efforts, Canadian researchers are better positioned to build on a baseline of observations that will help put future cryospheric changes in context. An important legacy of the IPY is an enhanced observing network that includes additional ground based, in situ monitoring sites and the development of new techniques to improve the retrieval of cryospheric parameters from satellite measurements. Long-term observations are needed to better characterize cryospheric trends and their inherent variability. Maintenance of these monitoring systems is necessary to extend time series and support improved assessments of cryospheric response to climate change. IPY related activities also facilitated the development of local monitoring projects and the engagement of northern residents in contributing their knowledge to the development of new datasets.

Innovative field campaigns: Field campaigns supported by Canadian IPY investment were ambitious and innovative, facilitated observations across regions which had not been systematically sampled before, and pursued new collaborative opportunities for cryospheric field work. For instance, observations of the ice shelves of northern Ellesmere Island were noteworthy not only for being the first surface-based ice thickness measurements in these regions, but for the collaborative nature of the campaign with university scientists working alongside Canadian Forces and Canadian Rangers personnel. Canadian and American scientists collaborated to make the first systematic snow measurements across the Canadian Barrenlands, during which they also filed daily audio, video, and pictorial updates to a website from the field. These posts were followed by primary school students from over 50 schools in Canada and the United States.

Results from Canadian IPY studies of terrestrial snow cover illustrate the connection between dataset development driven by field activities (including new satellite retrieval algorithms) and time series analysis. Investing in the development and improvement of remote sensing products through field campaign activities can make an immediate impact on climatological studies by providing new, enhanced time series for analysis. Combining validated datasets from satellite measurements, reanalysis, and conventional observations enhances our ability to statistically characterize change and variability (with associated uncertainty) over time.

Supportive collaborative structure for research groups: Canadian IPY research activities depended on collaboration between government and university researchers and northern organizations, residents, and students. This collaboration significantly enhanced data collection opportunities, while information sharing between individuals and organizations increased the analytical capacity of the projects.

Support for young researchers and training of young scientists: Training of young scientists was achieved by engaging students, at various academic levels, in the IPY projects. For example, approximately 100 students ranging from undergraduates to post-doctoral fellows participated in the cryosphere-related projects. Continued investment in Polar science within Canada is necessary to ensure future opportunities for the young scientists who were trained during IPY. 
It is our hope that the notable progress achieved on cryospheric research in Canada during IPY is sustained. Although there have been efforts during IPY to develop a framework for cryospheric observing networks, long-term commitment and investment will be required to ensure continued operation of the recently enhanced networks. Partnerships and joint monitoring sites, at which information for multiple key environmental variables are collected, will be essential. Adequate observations are essential for the development and validation of models to predict future cryospheric conditions, and to reduce uncertainties in these predictions. IPY activities show the potential benefits of collaboration between the observing and modelling communities.

\section{Conclusions}

Research during the IPY has provided new knowledge on the state and variability of the Canadian cryosphere. This information provides a baseline against which future change can be assessed. The fundamental conclusion is that there is strong evidence of temperatureinduced changes throughout the Canadian cryosphere, modulated by regional, decadal and interannual variability:

- Mean annual ground temperatures have increased by up to $0.2^{\circ} \mathrm{C}$ per decade since the mid 1980s in the central and southern Mackenzie Valley, $0.8^{\circ} \mathrm{C}$ per decade since the early 1970s across the tundra environments of the western Arctic, up to $1.2^{\circ} \mathrm{C}$ per decade in the eastern Arctic (northern Quebec), and almost $1^{\circ} \mathrm{C}$ per decade since the 1990s in the High Arctic.

- May and June snow cover extent decreased by $14 \%$ and $46 \%$ respectively over the panArctic during the 1967-2008 period in response to earlier snow melt; a new record low spring snow cover duration was observed over both the North American and Eurasian sectors of the Arctic during 2010.

- Over the period of 1968 to 2010, summer total sea ice cover decreased by $5.9 \%$ decade $^{-1}$ in the Southern Beaufort Sea, $3.6 \%$ decade $^{-1}$ in the CAA, $9.9 \%$ decade $^{-1}$ in Baffin Bay, $3.5 \%$ decade $^{-1}$ in Kane Basin, $9.2 \%$ decade $^{-1}$ in Foxe Basin, $10.5 \%$ decade $^{-1}$ in Hudson Bay, $16 \%$ decade $^{-1}$ in Hudson Strait, $14.2 \%$ decade $^{-1}$ in Davis Strait, and $17.3 \%$ decade $^{-1}$ in the North Labrador Sea. Historic sea ice events loss were noted during IPY. In 2007, the Northwest Passage route through the Western Parry Channel cleared for the first time in the satellite era.

- Extensive shrinkage of Yukon glaciers occurred between the 1957/58 IGY and the IPY. Surface mass balance of glaciers in the Queen Elizabeth Islands became extremely negative after 2005 in response to strong summer warming and longer melt seasons (especially in 2007-2009). Regional scale geophysical measurements suggest that total annual mass losses from glaciers and ice caps in the Canadian Arctic Islands reached $92 \pm 12$ Gt per year from 2007 to 2009. During this period, the Canadian Arctic Islands were probably the largest regional contributor to global sea level rise outside Greenland and Antarctica.

- Dramatic break-up events have greatly reduced the extent of ice shelves along the northern coast of Ellesmere Island, including complete losses of the Ayles Ice Shelf $\left(86 \mathrm{~km}^{2}\right)$ in 2005, and the Markham Ice Shelf $\left(50 \mathrm{~km}^{2}\right)$ in 2008.

The cryosphere is changing. Sustained efforts to comprehensively observe all elements of the cryosphere are necessary to understand the response to a changing global climate system, 
understand how these changes will affect terrestrial and marine ecosystems, and reduce the vulnerability of northern residents and northern development to risks associated with climate variability and change.

Acknowledgements The research in this paper was supported by the Federal Government of Canada IPY Program and the Natural Sciences and Engineering Research Council. Support was also provided by the government departments/organizations and academic institutions affiliated with the authors as well as numerous other agencies and institutions. The considerable support and assistance from individuals, communities and organizations across northern Canada was essential for the success of all the research projects. We are also grateful to numerous colleagues and students who contributed to data collection, management, processing and analysis. The support provided by the Federal IPY office and Tanuja Kulkarni (Aboriginal Affairs and Northern Development Canada) is greatly appreciated. We also thank Don Lemmen (Natural Resources Canada) for his extensive editing efforts which improved the manuscript, and two anonymous reviewers for their helpful comments.

\section{References}

Allison I, Ananicheva M, Burgess D, Gogineni P, Hagen J, Rachold V, Sharp M, Thing H (2011) Greenland Ice Sheet and Arctic Glaciers. In: Allison I, López-Martínez J (eds) Part 2 IPY Science Program (in Understanding Earth's Polar Challenges: International Polar Year 2007-2008). ICSU/WMO IPY Joint Committee, pp 215-232

Atkinson DE, Brown R, Alt B, Agnew T, Bourgeois J, Burgess M, Duguay C, Henry G, Jeffers S, Koerner R, Lewkowicz AG, McCourt S, Melling H, Sharp M, Smith S, Walker A, Wilson K, Wolfe S, Woo M-K, Young K (2006) Canadian cryospheric response to an anomalous warm summer: a synthesis of the Climate Change Action Fund Project "The state of the Arctic Cryosphere during the extreme warm summer of 1998". Atmosphere-Ocean 44(4):347-375

Barnett T, Adam J, Lettenmaier D (2005) Potential impacts of a warming climate on water availability in snow-dominated regions. Nature 438:303-309. doi:10.1038/nature04141

Barrand NE, Sharp MJ (2010) Sustained rapid shrinkage of Yukon glaciers since the 1957-1958 International Geophysical Year. Geophys Res Lett 37:L07501. doi:10.1029/2009GL042030

Brasnett B (1999) A global analysis of snow depth for numerical weather prediction. J App Meteorol 38:726-740

Brown L, Duguay CR (2010) The response and role of ice cover in lake-climate interactions. Prog Phys Geog 34(5):671-704. doi:10.1177/0309133310375653

Brown L, Duguay CR (2011) The fate of lake ice in the North American Arctic. Cryosphere 5(4):1775-1834

Brown R, Robinson D (2011) Northern Hemisphere spring snow cover variability and change over 19222010 including an assessment of uncertainty. Cryosphere 5:219-229

Brown R, Derksen C, Wang L (2010) A multi-dataset analysis of variability and change in Arctic spring snow cover extent, 1967-2008. J Geophys Res 115:D16111. doi:10.1029/2010JD013975

Burn CR, Kokelj SV (2009) The environment and permafrost of the Mackenzie Delta area. Permafr Periglac Process 20(2):83-105

Burn CR, Zhang Y (2009) Permafrost and climate change at Herschel Island (Qikiqtaruq), Yukon Territory, Canada. J Geophys Res 114(F02001):16. doi:10.1029/2008JF001087

Callaghan T, Johansson M, Prowse T (eds) (2011) Arctic cryosphere - changes and impacts. Scientific findings from the Snow, Water, Ice and Permafrost in the Arctic (SWIPA) Report. 2011, Ambio Vol XL, Supplement 1, 2011

Canadian Standards Association (2010) Technical Guide - infrastructure in permafrost: a guideline for climate change adaptation. CSA Special Publication Plus 4011-10

Clausi D, Qin K, Chowdhury M, Yu P, Maillard P (2010) MAGIC: MAp-Guided Ice Classification, Can. J Remote Sens 36(S1):S13-S25

Clifford D (2010) Global estimates of snow water equivalent from passive microwave instruments: history, challenges and future developments. Int J Remote Sens 31(14):3707-3726

Cohen J, Entekhabi D (1999) Eurasian snow cover variability and Northern Hemisphere climate predictability. Geophys Res Lett 26(3):345-348

Comiso JC (2006) Abrupt decline in the Arctic winter sea ice cover. Geophys Res Lett 33(L18504). doi:10.1029/2006GL027341 
Copland L, Mueller DR, Weir L (2007) Rapid loss of the Ayles Ice Shelf, Ellesmere Island, Canada. Geophys Res Lett 34(L21501)

Dee DP, Uppala SM, Simmons AJ, Berrisford P, Poli P, Kobayashi S, Andrae U, Balmaseda MA, Balsamo G, Bauer P, Bechtold P, Beljaars A, van de Berg L, Bidlot J, Bormann N, Delsol C, Dragani R, Fuentes M, Geer AJ, Haimberger L, Healy SB, Hersbach H, Hólm EV, Isaksen L, Kållberg P, Köhler M, Matricardi M, McNally AP, Monge-Sanz BM, Morcrette JJ, Park BK, Peubey C, de Rosnay P, Tavolato C, Thépaut JN, Vitart F (2011) The ERA-Interim reanalysis: configuration and performance of the data assimilation system. QJRMS 137(656):553-597. doi:10.1002/qj.828

Derksen C, Brown R (2011) Terrestrial Snow (Arctic). In state of the climate in 2010. Bull Am Meteorol Soc 92:S154-S155

Derksen C, Sturm M, Liston G, Holmgren J, Huntington H, Silis A, Solie D (2009) Northwest Territories and Nunavut snow characteristics from a sub-Arctic traverse: Implications for passive microwave remote sensing. J Hydromet 10(2):448-463

Derksen C, Toose P, Rees A, Wang L, English M, Walker A, Sturm M (2010) Development of a tundraspecific snow water equivalent retrieval algorithm for satellite passive microwave data. Remote Sens Environ 114(8):1699-1709

Dery S, Brown R (2007) Recent Northern Hemisphere snow cover extent trends and implications for the snow-albedo feedback. Geophys Res Lett 34(L22504). doi:10.1029/2007GL031474

Dibike Y, Prowse T, Bonsal B, de Rham L, Saloranta T (2011) Simulation of North American lake-ice cover characteristics under contemporary and future climate conditions. Int J Climatol Online Feb 92011. doi:10.1002/joc. 2300

Drever M, Clark R, Derksen C, Toose P, Nudds T, Slattery S (2011) Population vulnerability to climate change linked to timing of breeding in boreal ducks. Glob Chang Biol. doi:10.1111/j.1365-2486.2011.02541.x

Dugan HA, Lamoureux SF, Lafrenière MJ, Lewis T (2009) Hydrological and sediment yield response to summer rainfall in a small high Arctic watershed. Hydrol Processes 23:1514-1526. doi:10.1002/hyp.7285

Duguay C, Prowse T, Bonsal B, Brown R, Lacroix M, Ménard P (2006) Recent trends in Canadian lake ice cover. Hydrol Processes 20(4):781-801

Duncan A (2011) Spatial and temporal variations of the surface energy balance and ablation on the Belcher Glacier, Devon Island, Nunavut, Canada. M Sc thesis, University of Alberta

Ednie M, Smith SL (2010) Establishment of community-based permafrost monitoring sites, Baffin region, Nunavut. In: GEO2010, 63rd Canadian Geotechnical Conference \& 6th Canadian Permafrost Conference Calgary, 2010. GEO2010 Calgary Organizing Committee, pp 1205-1211

Ednie M, Smith SL (2011) Establishment of community-based permafrost monitoring sites and initial ground thermal data Baffin Region, Nunavut. Geological Survey of Canada Open File 6727

England JH, Lakeman TR, Lemmen DS, Bednarski J, Stewart TG, Evans D (2008) A millenial-scale record of Arctic Ocean sea ice variability and the vulnerability of the Ellesmere Island ice shelves. Geophys Res Lett 35(L19502). doi:10.1029/2008GL034470

Federal, Provincial \& Territorial Governments of Canada (2010) Canadian biodiversity: ecosystem status and trends 2010. Canadian Councils of Resource Ministers, Ottawa

Fernandes R, Zhao H, Wang X, Key J, Qu X, Hall A (2009) Controls on Northern Hemisphere snow albedo feedback quantified using satellite Earth observations. Geophys Res Lett 36 (L21702). doi:10.1029/ 2009GL040057

Fisher D, Zheng J, Burgess D, Zdanowicz C, Kinnard C, Sharp M, Bourgeois J (2012) Recent melt rates of Canadian arctic ice caps are the highest in four millennia. Global Planet Change 84-85:3-7. doi:10.1016/ j.gloplacha.2011.06.005

Fletcher CG, Kushner PJ, Hall A, Qu X (2009a) Circulation responses to snow albedo feedback in climate change. Geophys Res Lett 36(L09702). doi:10.1029/2009GL038011

Fletcher CG, Hardiman SC, Kushner PJ, Cohen J (2009b) The Dynamical Response to Snow Cover Perturbations in a Large Ensemble of Atmospheric GCM Integrations. J Climate 22:1208-1222

Francis J, White D, Cassano J, Gutkowski W, Hinzman L, Holland M, Steele M, Vorosmarty C (2009) An arctic hydrologic system in transition: feedbacks and impacts on terrestrial, marine, and human life. J Geophys Res 114(G04019). doi:10.1029/2008JG000902

Furgal C, Prowse TD (2008) Northern Canada. In: Lemmen DS, Warren FJ, Lacroix J, Bush E (eds) From impacts to adaptation: Canada in a changing climate 2007. Government of Canada, Ottawa, pp 57-118

Gardner AS, Moholdt G, Wouters B, Wolken GJ, Burgess DO, Sharp MJ, Cogley G, Braun C, Labine C (2011) Sharply increased mass loss from glaciers and ice caps in the Canadian Arctic Archipelago. Nature 473:357-360. doi:10.1038/nature10089

Gauthier Y, Tremblay M, Bernier M, Furgal C (2010) Adaptation of a radar-based river ice mapping technology to the Nunavik context. Can J Remote Sens 36(S1):168-185 
Hardiman SC, Kushner PJ, Cohen J (2008) Investigating the ability of general circulation models to capture the effects of Eurasian snow cover on winter climate. J Geophys Res 113(D21123). doi:10.1029/ 2008JD010623

Heginbottom JA, Dubreuil MA, Harker PA (compilers) (1995) Canada - Permafrost. The National Atlas of Canada (5th ed), Ottawa, ON. Geomatics Canada and Terrain Sciences Division, National Atlas Information Service and Geological Survey of Canada, Plate 2.1, (MCR 4177)

Hochheim KP, Barber DG (2010) Atmospheric forcing of sea ice in Hudson Bay during the fall period, 19802005. J Geophys Res 115(C05009). doi:10.1029/2009JC005334

Howell S, Duguay CR, Markus T (2009a) Sea ice conditions and melt season duration variability within the Canadian Arctic Archipelago: 1979-2008. Geophys Res Lett 36(L10502). doi:10.1029/2009GL037681

Howell S, Brown LC, Kang KK, Duguay CR (2009b) Variability in ice phenology on Great Bear Lake and Great Slave Lake, Northwest Territories Canada, from SeaWinds/QuikSCAT: 2000-2006. Remote Sens Environ 113(4):813-834. doi:10.1016/j.rse.208.12.007

Howell S, Tivy A, Agnew T, Markus T, Derksen C (2010) Extreme low sea ice years in the Canadian Arctic Archipelago: 1998 versus 2007. J Geophys Res 115(C10053). doi:10.1029/2010JC006155

James M (2010) Historic change in permafrost distribution in northern British Columbia and southern Yukon Territory, Canada. MSc Thesis, University of Ottawa, Ottawa, ON

James M, Lewkowicz AG, Smith SL (2010) Change in permafrost distribution in northern British Columbia and southern Yukon, Canada from 1964 to the 2007-2008 IPY. In: Mertes JR, Christiansen HH, Etzelmüller B (eds) Thermal state of frozen ground in a changing climate during the IPY, abstracts from the third European Conference on Permafrost, Longyearbyen, Svalbard, 2010. The University Centre in Svalbard, Svalbard

Jeffries MO (2002) Ellesmere Island ice shelves and ice islands. In: Williams RS, Ferrigno JG (eds) Satellite image atlas of glaciers of the World: North America. United States Geological Survey, Washington, pp J147-J164

Jia GJ, Epstein HE, Walker DA (2009) Vegetation greening in the Canadian Arctic related to decadal warming. J Environ Monit 11(12):2231-2238

Kalnay E et al (1996) The NCEP/NCAR reanalysis project. Bull Am Meterol Soc 77:437-471

Kang K, Duguay C, Howell S, Derksen C, Kelly R (2010) Sensitivity of AMSR-E brightness temperature to the seasonal evolution of lake ice thickness. IEEE Geosci Remote Sens Lett 7(4):751-755. doi:10.1109/ LGRS.2010.2044742

Kaufman DS, Schneider DP, McKay NP, Ammann CM, Bradley RS, Briffa KR, Miller GH, Otto-Bliesner BL, Overpeck JT, Vinther BM, Arctic Lakes 2k Project Members (2009) Recent warming reverses long-term Arctic cooling. Science 325(5945):1236-1239. doi:10.1126/science.1173983

Koerner RM (2005) Mass balance of glaciers in the Queen Elizabeth Islands, Nunavut, Canada. Ann Glaciol 42(1):417-423

Kokelj SV, Lantz TC, Kanigan J, Smith SL, Coutts R (2009a) Origin and polycyclic behaviour of tundra thaw slumps, Mackenzie Delta region, Northwest Territories, Canada. Permafr Periglac Process 20(2):173-184

Kokelj SV, Zajdik B, Thompson MS (2009b) The impacts of thawing permafrost on the chemistry of lakes across the subarctic boreal-tundra transition, Mackenzie Delta region. Permafr Periglac Process 20 (2):185-199. doi:10.1002/ppp.641

Kwok R, Rothrock DA (2009) Decline in Arctic sea ice thickness from submarine and ICES at records: 19582008. Geophys Res Lett 36(L15501). doi:10.1029/2009GL039035

LaFortune V, Furgal C, Drouin J, Annanack T, Einish N, Etidloie B, Qiisiq M, Tookalook P, Communities of Kangiqsujuaq, Kangiqsualujjuaq, \& Kawawachikamack (2004) Climate change in Northern Québec: access to land and resource issues. Project initiative of the Kativik Regional Government. Progress Report, internal report

Lamoureux SF, Lafrenière MJ (2009) Fluvial Impact of Extensive Active Layer Detachments, Cape Bounty, Melville Island, Canada. Arct Antarct Alp Res 41(1):59-68

Langlois A, Royer A, Goita K (2010) Analysis of simulated and spaceborne passive microwave brightness temperatures using in situ measurements of snow and vegetation properties. Can J Remote Sens 36(S1): S135-S148

Langlois A, Royer A, Dupont F, Roy A, Goïta K, Picard G (2011) Improved corrections of forest effects on passive microwave satellite remote sensing of snow over boreal and subarctic regions. IEEE Trans Geosci Remote Sens 49(10):3824-3837

Lantz TC, Kokelj SV (2008) Increasing rates of retrogressive thaw slump activity in the Mackenzie Delta region, N.W.T., Canada. Geophys Res Lett 35(L06502):5. doi:10.1029/2007GL032433

Lantz TC, Kokelj SV, Gergel SE, Henry GHR (2009) Relative impacts of disturbance and termperature: persitent changes in microenvironment and vegetation in retrogressive thaw slumps. Glob Chang Biol 15 (7):1664-1675 
Lemke P, Ren J, Alley RB, Allison I, Carrasco J, Flato G, Fujii Y, Kaser G, Mote P, Thomas RH, Zhang T (2007) Observations: changes in snow, ice and frozen ground. In: Climate Change 2007: the physical science basis. Contribution of Working Group 1 to the Fourth Assessment Report of the Intergovernmental Panel on Climate Change. Cambridge University Press, Cambridge, UK and New York, USA, pp $337-383$

Lenormand F, Duguay C, Gauthier R (2002) Development of a historical ice database for the study of climate change in Canada. Hydrol Processes 16(18):3707-3722

Lewkowicz AG, Bonnaventure PP (2011) Equivalent elevation: a new method to incorporate variable surface lapse rates into mountain permafrost modelling. Permafr Periglac Process 22(2):153-162. doi:10.1002/ ppp. 720

Lewkowicz AG, Etzelmüller B, Smith SL (2011) Characteristics of discontinuous permafrost from ground temperature measurements and electrical resistivity tomography, southern Yukon, Canada. Permafrost and Periglacial Processes. doi:10.1002/ppp.703

Markus T, Stroeve JC, Miller J (2009) Recent changes in Arctic sea ice melt onset, freeze-up, and melt season length. J Geophys Res 114 (C12024). doi:10.1029/2009JC005436

Maslanik JA, Fowler C, Stroeve J, Drobot S, Zwally HJ, Yi D, Emery WJ (2007) A younger, thinner Arctic ice cover: increased potential for rapid, extensive sea ice loss. Geophys Res Lett 34(L24501). doi:10.1029/ 2007GL032043

Mekis E, Vincent L (2011) An overview of the second generation adjusted daily precipitation dataset for trend analysis in Canada. Atmos Ocean 49:163-177

Melling H (2002) Sea ice of the northern Canadian Arctic Archipelago. J Geophys Res 107(C11):3181. doi:10.1029/2001JC001102

Mortimer C, Copland L, Mueller DR (in review) Volume and area changes of the Milne Ice Shelf, Ellesmere Island, Nunavut, Canada, since 1950. Journal of Geophysical Research - Earth Surface

Mueller DR, Pollard WH (2004) Gradient analysis of cryoconite ecosystems from two polar glaciers. Polar Biol 27(2):66-74

Mueller DR, Vincent WF, Jeffries MO (2006) Environmental gradients, fragmented habitats and microbiota of a northern ice shelf cryoecosystem, Ellesmere Island, Canada. Arct Antarct Alp Res 38(4):593-607

Mueller DR, Copland L, Hamilton A, Stern DR (2008) Examining Arctic ice shelves prior to 2008 breakup. Eos, Trans, Am Geophys Union 89(49):502-503

NRCC (1988) Glossary of Permafrost and Related Ground-ice Terms. Permafrost Subcommittee, National Research Council of Canada, Technical Memorandum 142

Pautler BG, Simpson AJ, McNally DJ, Lamoureux SF, Simpson MJ (2010) Arctic permafrost active layer detachments stimulate microbial activity and degradation of soil organic matter. Environ Sci Technol 44 (11):4076-4082

Payette S, Delwaide A, Caccianiga M, Beauchemin M (2004) Accelerated thawing of subarctic peatland permafrost over the last 50 years. Geophys Res Lett 31(L18208). doi:10.1029/2004GL020358

Pimentel S, Flowers GE (2010) A numerical study of hydrologically driven glacier dynamics and subglacial flooding. Proceedings of the Royal Society A. doi:10.1098/rspa.2010.0211

Pimentel S, Flowers GE, Schoof CG (2010) A hydrologically coupled higher order flow band model of ice dynamics with a Coulomb friction sliding law. J Geophys Res 115(F04023). doi:10.1029/2009JF001621

Pope S, Copland L, Mueller D (2012) Loss of multiyear landfast sea ice from Yelverton Bay, Ellesmere Island, Nunavut, Canada. Arctic, Antarctic, and Alpine Research 44(2)

Prestrud P (2007) Why are snow and ice important to us? Chapter 2. In: Eamer J (ed) UNEP Global Outlook for Ice \& Snow. United Nations Environment Program, pp 19-28

Prowse TD, Furgal C, Chouinard R, Melling H, Milburn D, Smith SL (2009) Implications of climate change for economic development in Northern Canada: energy, resource, and transportation sectors Ambio 38 (5):272-281

Rahmstorf S (2010) Has the IPCC underestimated the risk of sea level rise? Nature Reports Climate Change, 6 April 2010. doi:10.1038/climate.2010.29

Rawlins M, Steele M, Holland M, Adam J, Cherry J, Francis J, Groisman P, Hinzman L, Huntington T, Kane D, Kimball J, Kwok R, Lammers R, Lee C, Lettenmaier D, McDonald K, Podest E, Pundsack J, Rudels B, Serezze M, Shiklomanov A, Skagseth Ø, Troy T, Vorosmarty C, Wensnahan M, Wood E, Woodgate R, Yang D, Zhang K, Zhang T (2010) Analysis of the Arctic system for freshwater cycle intensification: observations and expectations. J Clim 23:5715-5737

Rignot E, Box J, Burgess E, Hanna E (2008) Mass balance of the Greenland ice sheet from 1958 to 2007. Geophys Res Lett. doi:10.1029/2008GL035417

Romanovsky VE, Smith SL, Christiansen HH (2010) Permafrost thermal state in the polar Northern Hemisphere during the International Polar Year 2007-2009: a synthesis. Permafr Periglac Process 21:106-116 
Serreze M, Walsh J, Chapin F III, Osterkamp T, Dyurgerov M, Romanosky V, Oechel W, Morison J, Zhang T, Barry R (2000) Observational evidence of recent change in the northern high-latitude environment. Clim Chang 46:159-207

Serreze M, Holland M, Stroeve J (2007) Perspectives on the Arctic's Shrinking Sea-Ice Cover. Science 316:1533-1536

Serreze M, Barrett A, Stroeve J, Kindig D, Holland M (2009) The emergence of surface-based Arctic amplification. Cryosphere 3:11-19

Sharp M, Wolken G (2010) Glaciers outside of Greenland. In: Richter-Menge J, Overland JE (eds) Arctic Report Card 2010. pp 48-54. http://www.arctic.noaa.gov/reportcard

Sharp M, Wolken G (2011) Glaciers outside Greenland. In: State of the Climate in 2010. Bull Am Meteorol Soc 92(6):S155-S156

Sharp M, Burgess DO, Cogley JG, Ecclestone M, Labine C, Wolken G (2011) Extreme melt on Canada's Arctic ice caps in the 21st century. Geophys Res Lett 38(L11501). doi:10.1029/2011GL047381

Shiklomanov AI, Lammers RB (2009) Record Russian river discharge in 2007 and the limits of analysis. Environ Res Lett 4(045015). doi:10.1088/1748-9326/4/4/045015

Smith SL, Burgess MM (2000) Ground temperature database for northern Canada. Geological Survey of Canada Open File 3954

Smith SL, Burgess MM, Heginbottom JA (2001) Permafrost in Canada, a challenge to northern development. In: Brooks GR (ed) A Synthesis of Geological Hazards in Canada. Geological Survey of Canada. Bulletin 548:241-264

Smith SL, Burgess MM, Riseborough DW (2008) Ground temperature and thaw settlement in frozen peatlands along the Norman Wells pipeline corridor, NWT Canada: 22 years of monitoring. In: Kane DL, Hinkel KM (eds) Ninth International Conference on Permafrost, Fairbanks Alaska,. Institute of Northern Engineering, University of Alaska Fairbanks, pp 1665-1670

Smith SL, Chartrand J, Nguyen TN, Riseborough DW, Ednie M, Ye S (2009) Geotechnical database and descriptions of permafrost monitoring sites established 2006-07 in the central and southern Mackenzie Corridor. Geological Survey of Canada Open File 6041

Smith KL, Fletcher CG, Kushner PJ (2010a) The role of linear interference in the annular mode response to extratropical surface forcing. J Climate 23:6036-6050

Smith SL, Romanovsky VE, Lewkowicz AG, Burn CR, Allard M, Clow GD, Yoshikawa K, Throop J (2010b) Thermal state of permafrost in North America - A contribution to the International Polar Year. Permafr Periglac Process 21:117-135

Smith SL, Lewkowicz AG, Burn CR, Allard M, Throop J (2010c) The thermal state of permafrost in Canada Results from the International Polar Year. In: GEO2010, 63rd Canadian Geotechnical Conference and the 6th Canadian Permafrost Conference, Calgary, Sept 2010. GEO2010 Calgary Organizing Committee, pp 1214-1221

Solomon SM, Taylor AE, Stevens CW (2008) Nearshore ground temperatures, seasonal ice bonding, and permafrost formation within the bottom-fast ice zone, Mackenzie Delta, NWT. In: Kane DL, Hinkel KM (eds) Proceedings of the Ninth International Conference on Permafrost, Fairbanks, Alaska. Institute of Northern Engineering, University of Alaska Fairbanks, Fairbanks, pp 1675-1680

Sou T, Flato G (2009) Sea Ice in the Canadian Arctic Archipelago: modeling the past (1950-2004) and the future (2041-60). J Clim 22:2181-2198. doi:10.1175/2008JCLI2335.1

Stephenson SR, Smith LC, Agnew JA (2011) Divergent long-term trajectories of human access to the Arctic. Nature Climate Change. doi:10.1038/NCLIMATE1120

Stevens CW, Moorman BJ, Solomon SM (2010) Modelling ground thermal conditions and the limit of permafrost within the near-shore zone of the Mackenzie Delta, Canada. Journal Geophysical Research 115 (F04027)

Stroeve J, Serreze M, Drobot S, Gearheard S, Holland M, Maslanik J, Meier W, Scambos T (2008) Arctic sea ice extent plummets in 2007, Eos Trans. AGU 89(2). doi:10.1029/2008EO020001

Stroeve J, Serreze M, Holland M, Kay J, Maslanik J, Barrett A (2011) The Arctic's rapidly shrinking sea ice cover: a research synthesis. Clim Chang. doi:10.1007/s10584-011-0101-1

Takala M, Luojus K, Pulliainen J, Derksen C, Lemmetyinen J, Kärnä JP, Koskinen J (2011) Estimating northern hemisphere snow water equivalent for climate research through assimilation of space-borne radiometer data and ground-based measurements. Remote Sens Environ. doi:10.1016/j.rse.2011.08.014

Thibault S, Payette S (2009) Recent permafrost degradation in bogs of the James Bay area northern Quebec, Canada. Permafr Periglac Process 20:383-389

Throop JL (2010) Spatial and temporal variability in permafrost conditions, northern Canada. MSc Thesis, University of Ottawa, Ottawa

Throop JL, Smith SL, Lewkowicz AG (2010) Observed recent changes in climate and permafrost temperatures at four sites in northern Canada. In: GEO2010, 63rd Canadian Geotechnical Conference and the 6th Canadian Permafrost Conference, Calgary. GEO2010 Calgary Organizing Committee, pp 1265-1272 
Throop JL, Lewkowicz AG, Smith SL (2012) Climate and ground temperature relations at sites across the continuous and discontinuous permafrost zones, northern Canada. Can J Earth Sci 49. doi:10.1139E11-075

Tivy A, Howell S, Alt B, McCourt S, Chagnon R, Crocker G, Carrieres T, Yackel J (2011a) Trends and variability in summer sea ice cover in the Canadian Arctic based on the Canadian Ice Service Digital Archive, 1960-2008 and 1968-2008. 2011. J Geophys Res 116(C03007). doi:10.1029/2009JC005855

Tivy A, Howell S, Alt B, Yackel JJ, Carrieres T (2011b) Origins and levels of seasonal forecast skill for sea ice in Hudson Bay using Canonical Correlation Analysis. J Clim 24. doi:10.1175/2010JCLI3527.1

Tremblay M, Furgal C, Larrivee C, Annanack T, Tookalook P, Qiisik M, Angiyou E, Swappie N, Savard JP, Barrett M (2008) Climate change in Northern Quebec: adaptation strategies from community-based research. Arctic, Supplement: 1-124: Arctic Change and Coastal Communities 61 (5): ISSN 1923-1245

Vallée S, Payette S (2007) Collapse of permafrost mounds along a subarctic river over the last 100 years (northern Québec). Geomorphology 90:162-170

Van Wychen W (2010) Spatial and temporal variations in ice motion, Belcher Glacier, Devon Island, Nunavut, Canada. M.Sc thesis, University of Ottawa

Vincent WF, Whyte LG, Lovejoy C, Greer CW, Laurion I, Suttle CA, Corbeil J, Mueller DR (2009) Arctic microbial ecosystems and impacts of extreme warming during the International Polar Year. Polar Science 3:171-180

Walsh JE, Anisimov O, Hagen J, Jakobsson T, Oerlemans J, Prowse TD, Romanovsky V, Savelieva N, Serreze M, Shiklomanov A, Shiklomanov I, Solomon S (2005) Cryosphere and hydrology. In: Arctic climate impact assessment. Cambridge University Press, New York, pp 183-242

Wang L, Wolken G, Sharp M, Howell S, Derksen C, Brown R, Markus T, Cole J (2011) Integrated pan-Arctic melt onset detection from satellite active/passive microwave measurements, 2000-2009. J Geophys Res. doi:10.1029/2011JD016256

Wilhelm R, Niederberger T, Greer C, Whyte LG (2011) Microbial diversity of active layer and permafrost in an acidic wetland from the Canadian high Arctic. Can J Microbiol 7:303-315

World Meteorological Organization (WMO) (2007) Cryosphere Theme Report. Integrated Global Observing Strategy. WMO/TD-No. 1405

Zhang X, Zwiers F, Hagerl G, Lambert F, Gillet N, Solomon S, Stott P, Nozawa T (2007) Detection of human influences on twentieth-century precipitation trends. Nature. doi:10.1038/nature06025 